\title{
Reconciling identity leadership and leader identity: A dual-identity framework
}

S. Alexander Haslam¹, Amber M. Gaffney ${ }^{2}$, Michael A. Hogg ${ }^{3}$, David E. Rast III ${ }^{4}, \&$ Niklas K. Steffens ${ }^{1}$

\footnotetext{
${ }^{1}$ School of Psychology, The University of Queensland

${ }^{2}$ Department of Psychology, Humboldt State University

${ }^{3}$ Department of Psychology, Claremont Graduate University

${ }^{4}$ Psychology Department, University of Alberta
}

Corresponding author:

Alex Haslam, School of Psychology, The University of Queensland, Brisbane, QLD 4072, Australia; Tel: +61 (0)73346 7345; email: a.haslam@uq.edu.au

Accepted manuscript for publication in The Leadership Quarterly, Editorial of special issue on Social Identity and Leadership:

Haslam, S. A., Gaffney, A. G., Hogg, M. A., Rast III, D. E., \& Steffens, N. K. (2022). Reconciling identity leadership and leader identity: A dual-identity framework. The Leadership Quarterly.

This is the accepted, non-corrected version of the article that may not exactly replicate the final, printed version of the article. 


\begin{abstract}
Research exploring the powerful links between leadership and identity has burgeoned in recent years but cohered around two distinct approaches. Research on identity leadership, the main focus of this special issue, sees leadership as a group process that centers on leaders' ability to represent, advance, create and embed a social identity that they share with the collectives they lead — a sense of "us as a group". Research on leader identity sees leadership as a process that is advanced by individuals who have a well-developed personal understanding of themselves as leaders - a sense of "me as a leader". This article explores the nature and implications of these divergent approaches, focusing on their specification of profiles, processes, pathways, products, and philosophies that have distinct implications for theory and practice. We formalize our observations in a series of propositions and also outline a dual-identity framework with the potential to integrate the two approaches.
\end{abstract}

Key words: leader identity, identity leadership, social identity, self-categorization 


\section{Reconciling identity leadership and leader identity: A dual-identity framework}

Uncontroversially, leadership is customarily defined as the process through which one or more members of a group influence other group members in a way that motivates them to contribute to the achievement of group goals (Haslam et al., 2015, Hogg et al., 2012a; House et al., 2002; Rost, 2008; van Knippenberg, 2012). Because it is essential for both social progress and social change, leadership is highly prized and is an ongoing focus for academic and public debate. Indeed, in fields as diverse as politics and religion, science and technology, sport and adventure, industry and business, leadership is widely considered to be the key process through which people are mobilized to work together to make history.

As it has evolved, this debate about leadership has seen many twists and turns and many fads and fashions have come and gone. As Gunter and Rayner (2021) observe, leadership is a field constantly in search of "the next big thing" (see also Alvesson \& Einola, 2019). Yet, as these researchers note, the field is also characterized by a number of constants. One of these is growth (Alvesson, 2019; Antonakis et al., 2019). Illustrative of this, over the last 20 years the number of books on leadership that are published every year has trebled (Maskor et al., 2021), while the number of peer-reviewed research articles that are published annually has increased linearly by a factor of 6 (see Figure 1a). A second constant is the drive to understand leadership as a process characterized by the distinct psychology of exceptional individuals — the "special something" that brands effective leaders as superior to the rankand-file members of the groups they lead. This approach has provenance dating back to the writings of Plato and Heraclitus and seminal reflections by Carlyle (1840, p.5) on leaders as "great men", but it continues to inform a broad range of leader-centric models of leadership to the present day (see Haslam et al., 2020, for a review). 


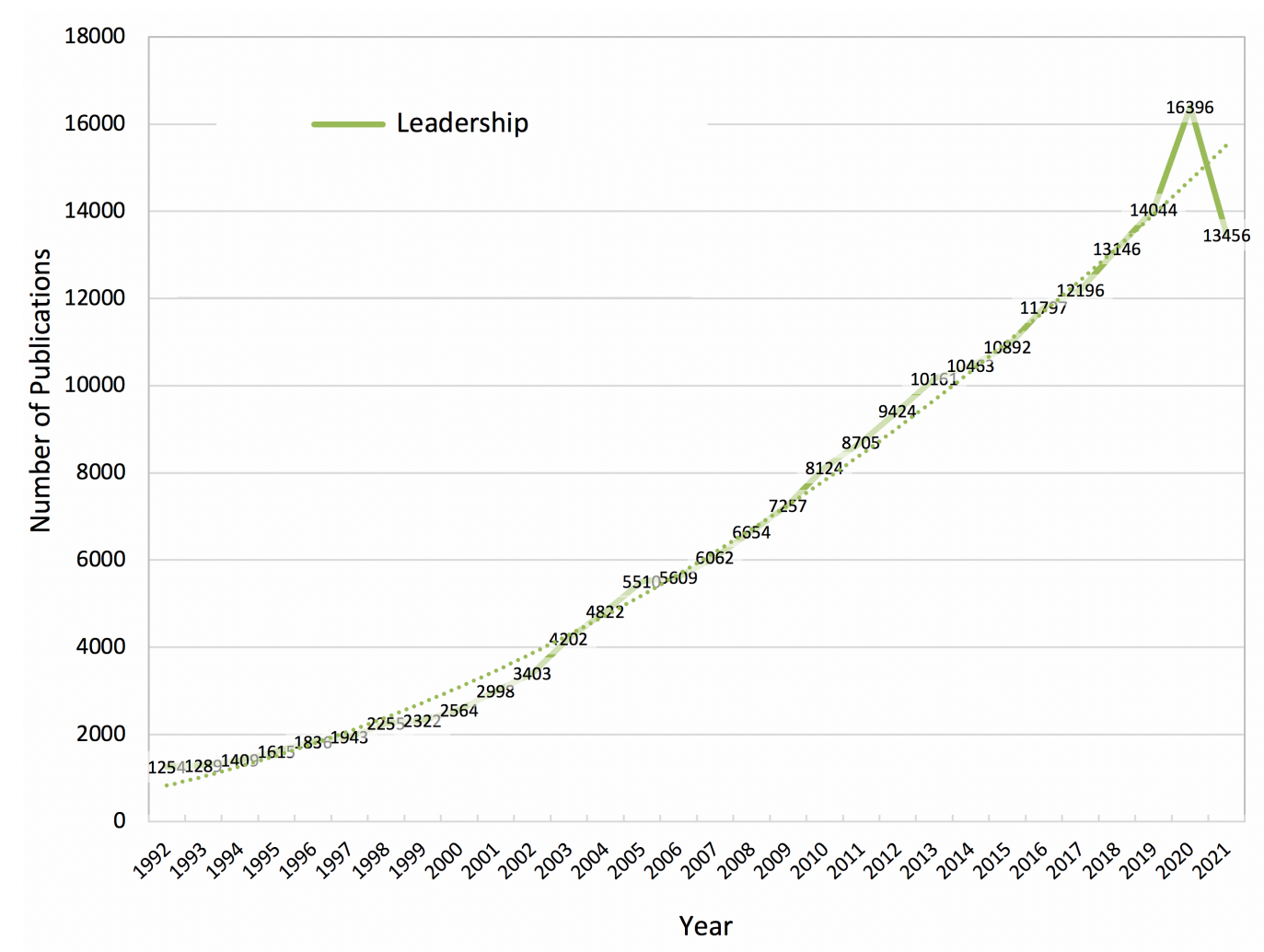

Figure 1a Number of publications on "leadership" by year.

Note: Data from a Scopus search of article titles, abstracts and keywords on October 12, 2021.

Against this backdrop, however, leadership research has seen one increasingly influential movement emerge in recent years - one that focuses on questions of identity. Broadly speaking, this conceptualizes leadership as a process that is grounded in the selfrelated understandings of leaders and those they are seeking to lead. This is then fleshed out in work that explores how these understandings bear upon multiple aspects of the various contexts in which leaders are trying to influence others (Epitropaki et al., 2017; Ibarra et al., 2014; van Knippenberg et al., 2004, 2005). In a nutshell, what all this research shows is that who leaders think they are and who others—notably would-be followers-think leaders are has a very significant bearing on leaders' capacity to lead effectively. The growth of this movement can be seen in Figure 1b. Here, alongside the linear growth in all forms of leadership research that we noted above, one can see that work on leadership and identity has 
increased by a factor of 25 since the turn of the millennium, and that this growth has been exponential.

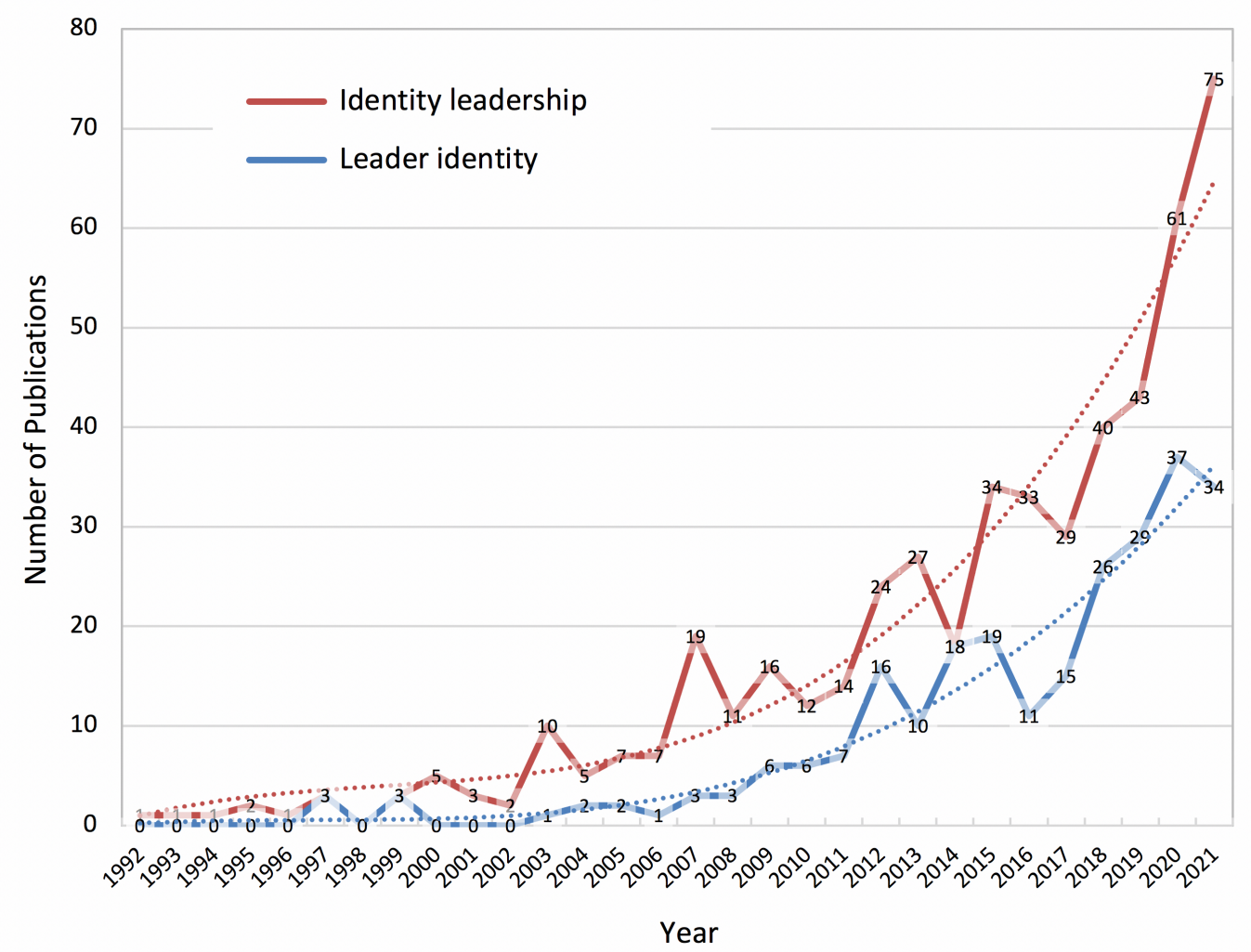

Figure $1 b$ Number of publications on (a) "identity leadership" (or "social identity" and “leadership"), (b) "leader identity" (or "self-identity" and "leadership") by year.

Note: Data from a Scopus search of article titles, abstracts and keywords on October 12, 2021.

The goal of this review (and the special issue that it introduces), is to map out some of the key features of this movement with a view to appreciating not just what it has achieved, but also where it is going. We do so primarily by zeroing in on two distinct strands of research on leadership and identity whose relationship to each other has previously been unclear. One of these strands focuses on the identity of leaders as individuals (work on leader identity); the other focuses on the identity of leaders as group members (work on identity leadership informed by the social identity model of leadership). As we will see, these two strands of research provide researchers and practitioners with divergent understandings of core aspects of the leadership process. In particular, they differ markedly in their 
articulation of leader profiles, psychological processes, development pathways, practitioner products, and social and organizational philosophies.

However, in what follows, as well as mapping out these differences, we also seek to shed some light on ways in which they might be integrated and reconciled (in ways recommended by Avolio, 2007; Elsbach \& van Knippenberg, 2020; Stets \& Burke, 2000). More specifically, we formulate a dual-identity framework and an associated series of propositions that together set out an emergent agenda for theoretical and practical progress. Before developing this framework, though, we set the scene for this review and for the special issue as whole by explaining what identity leadership and leader identity are about.

\section{Two approaches to identity and leadership}

\section{Identity leadership}

Work on the social identity model of leadership — and identity leadership more generally - is informed by two influential social psychological theories: social identity theory (SIT; Tajfel \& Turner, 1979) and self-categorization theory (SCT; Turner et al. 1987). The critical contribution of social identity theory is to recognize that, in a range of social and organizational contexts, people's sense of self is not primarily defined by their sense of themselves as individuals (in terms of their personal identity, as "me" and "I"; Turner, 1982).

Rather, it is defined by their sense of themselves as members of particular groups (in terms of their social identity, as “we” and "us"; Tajfel, 1972; see also Ellemers \& Haslam, 2012; Hogg \& Abrams, 1988). Through its capacity to structure people's sense of self, SIT also argues that social identity has wide-ranging implications for cognition and behavior — three of which are especially important.

First, when people define themselves in terms of a given social identity they are motivated to see that (in)group ('us') as positively distinct from other comparison (out)groups ('them'; Ashforth \& Kreiner, 1999; Brewer, 1991). In simple, terms we want the 
groups that matter to us to be special. Second, when a particular social identity is salient (i.e., psychologically operative in ways that contribute to a sense of social identification; Oakes et al. 1994) we are focused, above all else, on the fate and standing of the relevant group. For example, if a female cyclist defines herself as a member of a particular cycling team, what matters in a team pursuit is not her personal time but her team's time. Consequently, social identification makes people willing to act against their personal interests in order to advance the cause of a salient ingroup in ways that give rise to phenomena such as altruism, organizational citizenship and self-sacrifice (Antonakis, d'Adda et al., 2021; Ashforth \& Mael, 1989; Haslam, 2001; Levine et al., 2002). And third, whether and how social identity shapes behavior will depend heavily on people's understanding of the social context in which they find themselves. In particular, people's behavior will depend on the extent to which group boundaries are seen to be impermeable (e.g., so that it is impossible to leave a lowstatus group), and the degree to which intergroup relations are perceived to be unstable and illegitimate (e.g., Ellemers, 1993; Reicher \& Haslam, 2006).

Despite the richness of its ideas, there are some core questions about the operation of social identity that SIT does not address. What makes social identity salient? How is social identity shared and coordinated within groups? And how do individuals differ in their capacity to embody and enact social identity? It was partly to answer such questions that SCT was developed in the 1980 s. Its primary contribution was to argue that social identity makes group behavior possible through a process of depersonalization in which the self comes to be perceived as categorically interchangeable with others who are defined as ingroup members in a particular context (Turner, 1982; Turner et al., 1987, 1994). In other words, people are only able to work as a group because — and to the extent that depersonalized self-categorization leads them to see themselves and others as members of the same social category ('us'; Hogg \& Turner, 1987). 
This argument rests upon a model of the self as a categorical system in which the self can be defined (and hence can inform behavior) at different levels of abstraction. At the most concrete and exclusive level it is defined by personal identity which includes only the individual (Turner, 1982), but it can also be defined more inclusively by a social identity which includes other members of a salient ingroup (Oakes et al., 1994; Turner et al., 1897). Critically, though, as well as providing a psychological platform for group behavior, SCT argues that social identity provides a platform for particular people to guide and shape that behavior through processes of social influence (Turner, 1991). In other words, social identity is a basis for leadership (Hogg, 2001; Turner \& Haslam, 2001).

A key point here is that when a person defines themselves in terms of a particular social identity (e.g., as a feminist), they will be motivated both to discover the meaning of that social identity (e.g., what it means to be a feminist) and to act in ways that embody that meaning. But in a changing and uncertain world, these things may be hard to discern (Gaffney et al., 2018; Hogg, 2007, 2021). Accordingly, to makes sense of the world and our place within it, we rely on information from other people who are members of our ingroup (Turner, 1991). But clearly not everyone is going to be helpful here. If you are a feminist, it makes no sense to look to an antifeminist or a non-feminist for guidance on matters related to gender relations. Instead, you turn to fellow ingroup members (i.e., other feminists) because you see them as best positioned to inform you about self-relevant features of social reality (Hogg et al., 1990).

More particularly, SCT suggests that we will see others as qualified to inform us about a given social identity — and hence seek out and respond positively to their leadership — to the extent that they are perceived to be representative of a relevant ingroup (Hogg, 2001; Platow et al., 2006; Platow \& van Knippenberg, 2001). Stated more formally in the language of cognitive theorizing about the structure of categories, we are influenced by others to the extent that they are seen to be prototypical of a relevant ingroup (Hogg, 2001; Turner, 1991; Turner \& Haslam, 
2001; van Knippenberg, 2011). Following the principle of meta-contrast, SCT also argues that any individual group member will be seen to be more representative of an ingroup, and hence more influential within it, to the extent that they are seen to embody both what "we" have in common and what makes "us" different from other groups (Turner \& Haslam, 2001). Moreover, ceteris paribus the more prototypical a person is of a group with which we identify the more we will be motivated to follow them.

These ideas were initially integrated and formalized within the social identity theory of leadership (Hogg, 2001). They have since been confirmed by a large body of research which shows that people are more receptive to the leadership of those who are more prototypical of a relevant group (for reviews, see Hogg et al., 2012a; Hogg \& van Knippenberg, 2004; Platow et al., 2015). In particular, this relationship was confirmed in two meta-analyses. The first included 35 independent studies with a total of over 6,000 participants (where $r=.49$; Barreto \& Hogg, 2017); the second included 128 studies with over 30,000 participants (where $r=.38$; Steffens et al. 2021). Importantly, the latter study confirmed that this relationship was also present in the subset of studies that used experimental designs (where $r=.23$ ) and which were therefore able to establish the causal impact of prototypicality. And as well as confirming that more prototypical leaders are evaluated more favorably, this study also showed that leaders' group prototypicality predicted their behavioral impact — that is, whether their leadership translated into others' followership (in ways explored by Haslam \& Platow, 2001; Platow et al., 2015).

At the same time, though, other research inspired by social identity theorizing has shown that leaders' prototypicality is not all that matters when it comes to motivating followers (Halevy et al., 2011). As well as being perceived to be "one of us" leaders also need to be seen to "do it for us" through their work as ingroup champions (Haslam et al., 2001). Indeed, one of the things that is most problematic for leaders' effectiveness is the perception that they are either acting for themselves or, worse, for an outgroup (Hogg et al., 
2012a). In this vein another large body of research shows that regardless of how prototypical they are, leaders will be more effective when they are also seen to act in ways that advance group interests (Giessner et al., 2013; Steffens et al., 2013; see Haslam et al., 2020, for a review).

The foregoing analysis assumes, however, that in any given situation there will always be a pre-existing social identity for leaders to represent and advance. Moreover, the process envisioned here is a rather passive one in which leaders can only be successful if circumstances foist the mantle of prototypicality on their shoulders. How can leaders be creative drivers of change, if they need always to represent and advance the interests of others? A key point here is that social identities are not set in stone, but instead are a moveable feast. Indeed, one of the hallmarks of effective leadership is precisely the ability to take advantage of this flexibility. More specifically, work by Reicher and Hopkins (2000; Reicher et al., 2005) suggests that leaders need to be entrepreneurs of social identity who work not only to create a sense of shared group membership amongst would-be followers but also to shape their understanding of social identity.

In these terms, the first task of a would-be leader is to create a sense that they and their followers are bound together by a common cause which they embody (Haslam et al., 2020; Maskor et al., 2020). This endeavor will often center on the task of bringing members of diverse groups together in ways that create a superordinate sense of shared social identity. At the same time, though, a key challenge here is to build a superordinate "us" in ways that do not threaten subgroup distinctiveness or create intergroup threat- something that can be done by creating a relational intergroup identity (Hogg, 2015; Hogg et al., 2012b; Kershaw et al., 2020).

Again, though, these endeavors are not enough to guarantee success, especially in the long term. For leadership is not only about the behavior of leaders but also about the way 
they shape the behavior of followers (Bennis, 1999; Hollander, 1992; Platow et al., 2015). Accordingly, leaders need to fashion social identity in ways that are compelling for followers and that allow them to act in ways that embed shared group values in social reality. That is, they need to be identity impresarios who devise and choreograph collective activities and events that bring the groups they lead to life and give them a material force (Haslam et al., 2011).

This observation speaks to evidence from the organizational literature that leaders need to be "initiators of structure" (Fleishman, 1995; Judge et al., 2004; Peters \& Waterman, 1982). But it also suggests that these structures need to be ones that help group members collectively realize their aspirations for "us". In the political realm, the importance of this point is underlined by the power of rallies and marches to mobilize and galvanize followers (Reicher \& Haslam, 2017). But the form that such activities take necessarily varies as a function of nature of the social identity that leaders are seeking to entrench. Nevertheless, whatever the domain, the long-term effectiveness of groups and leadership is generally buttressed by formalized identity performances and structures-such things as competitions and conferences, feasts and festivals, ceremonies and celebrations.

Early work on social identity and leadership focused mainly on leaders' identity prototypicality. However, as it has evolved, social identity research has broadened out to also explore leaders' identity advancement, identity entrepreneurship and identity impresarioship. In 2011, this work was brought together in the first edition of Haslam, Reicher and Platow's monograph The New Psychology of Leadership. This showcased the work of around 50 researchers who had contributed to research on social identity and leadership at that time (a number that had grown to more than 150 by the time the second edition was published in 2020). To capture the breadth of social identity processes understood to be implicated in the 
leadership process it also referred to this work as being broadly concerned with identity leadership.

As Figure 1 makes clear, over the ensuing decade, a substantial body of research has served to take this agenda forward. In particular, alongside continued efforts to understand how identity leadership "works” (e.g., Gaffney et al., 2018, 2019; Giannella et al., 2022*1; Haslam et al., 2019; Rast et al., 2018; Sewell et al., 2022*; Smith et al., 2018) and what effects it has (e.g., Fransen, McEwan et al., 2020; McLaren et al., 2021; Miller et al., 2021; Stevens et al., 2019, 2021), researchers have been keen both to refine its assessment (Steffens et al., 2014, van Dick et al., 2018) and to explore its applied relevance across diverse fields. As a result, work on identity leadership now has very broad reach. Not only does it take place all around the world (van Dick et al., 2018; van Dick \& Kerschreiter, 2016) but so too its concerns extend well beyond the traditional focus of leadership research on questions of work and organization. Today, then, as Figure 2 attests, the frontiers of research on social identity and leadership are found in fields as far-flung as sport (Fransen et al., 2015, 2016; Haslam et al., 2020; Krug et al., 2020; McLaren et al., 2021; Slater \& Barker, 2019), health (Haslam et al., 2019; Lee et al., 2021), exercise (Miller et al., 2021; Stevens et al., 2021; Steffens et al., 2019), politics (Crano \& Gaffney, 2021; Gaffney et al., 2014; Mols et al., 2022; Jetten et al., 2021), economics (Akerlof, 2020; Steffens et al., 2020), and theology (Barentsen, 2015; Esler, 2021). As Akerlof (2020, p.xx) observes, the social identity approach is one for all our "we's".

$1 *$ denotes a paper included in this special issue 

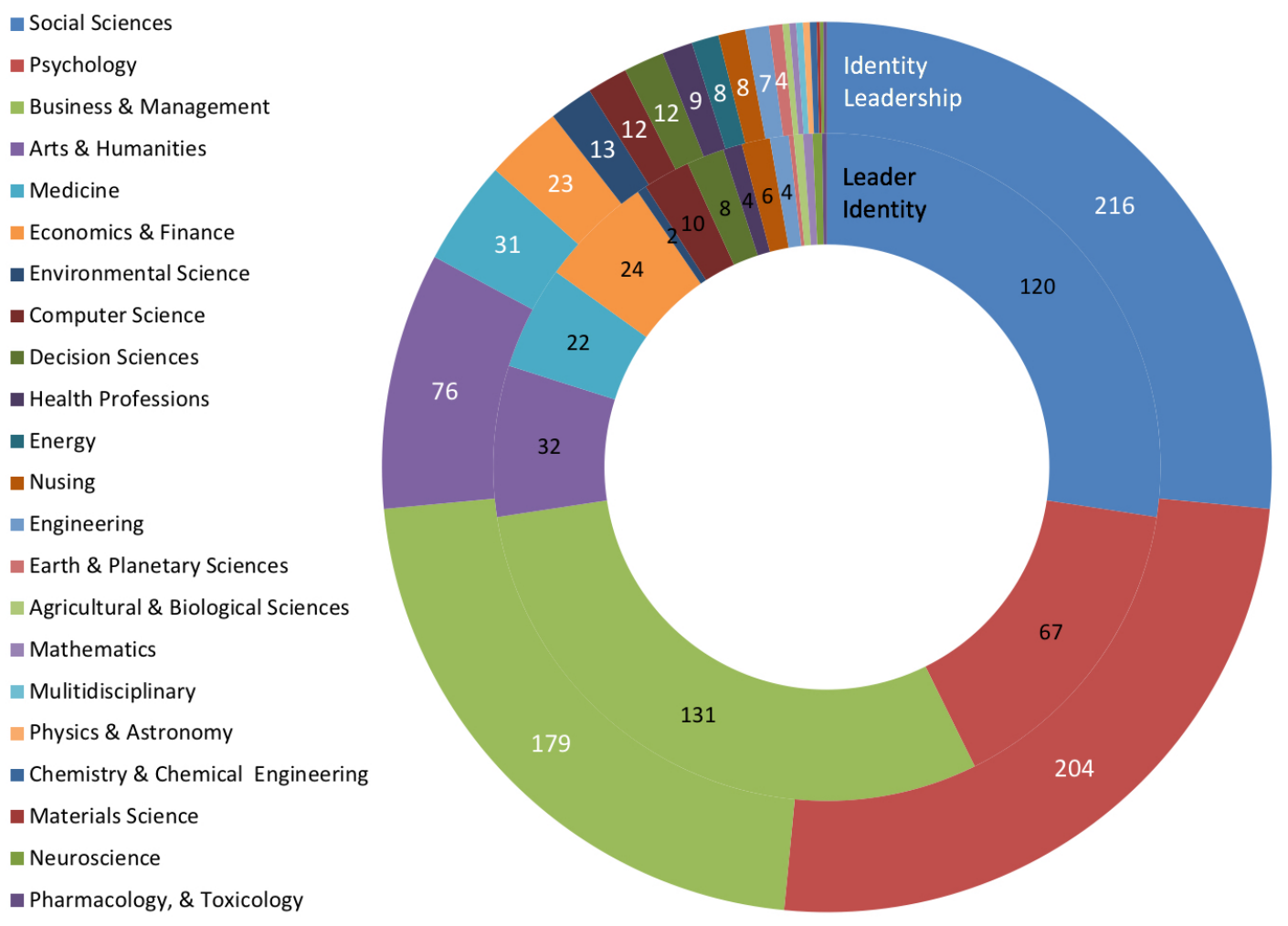

Figure 2 Number of publications on (a) "identity leadership" (or "social identity" and "leadership"), (b) "leader identity" (or "self-identity" and "leadership") by research field.

Note: Data from a Scopus search of article titles, abstracts and keywords on October 12, 2021.

\section{Leader identity}

Where research on identity leadership zeroes in on leaders' "we-ness", research on leader identity focuses firmly on their "I-ness". At heart, this focus means that it sees leadership as a process that is facilitated and furthered by individuals who have a welldeveloped personal understanding of themselves as leaders (a sense of "me as a leader") and who also succeed in getting others to accept this understanding. And whereas there are multiple perspectives that have explored different facets of this process, in different ways they all stress the importance of this interplay between leader behavior and follower perceptions (Epitropaki et al., 2017). 
Much of the pioneering work that fleshed out these ideas was conducted by Lord and his colleagues, who focused on the importance of leader prototypes (e.g., Lord et al., 1984; Lord \& Maher, 1990, 1991). They argued that in order for their leadership to be successful, individuals need to embody traits and attributes that are characteristic of leaders in the sphere in which they are seeking to have influence and that are consistent with followers' expectations of appropriate leader behavior. Accordingly, from this perspective, leadership is understood to be "a cognitive knowledge structure held in the memory of perceivers [where] perceivers use degree of match to this ready-made structure to form leadership perceptions" (Lord \& Maher, 1990, p.132). Building on these ideas, more recent work has focused on the need for leaders to communicate values that speak to followers' identities and that allow them to be seen as role models by those followers in ways that serve as a basis for their own self-regulation (Lord et al., 2001; Lord \& Brown, 2004; see also Kark \& van Dijk, 2007; Moss et al., 2009).

As was the case with SCT, original formulations of these ideas were based on cognitive research into the structure of natural categories (e.g., Rosch, 1978), and argued that these prototypes represent relatively stable, enduring expectations defined at different levels of abstraction. In particular, original statements of leadership categorization theory (Lord et al., 1984) suggested that followers have a range of hierarchically-organized leadership prototypes (with prototypes at lower levels being more concrete and more exclusive) which provide them with a set of expectations regarding a potential leader's appropriate traits and behaviors. At a superordinate level leaders are expected to share a number of common attributes (e.g., intelligence, honesty, and outgoingness), but Lord and colleagues (1984) identify a range of lower-level "basic" categories where possession of certain attributes differentiates between leaders in different domains (e.g., between sports and business leaders). 
Because LCT suggests that these prototypes are relatively fixed determinants of leader effectiveness, it also argues that where two basic-level categories are characterized by a minimal level of content overlap, leaders who are effective in one domain (because their behavior is consistent with the prototype for that domain) can nevertheless find it difficult to be effective in the other. Among other things, this analysis can help to explain the observed difficulty that popular leaders in one arena (e.g., the military or sport) can have in gaining acceptance in another (e.g., business or politics) as well as the broader contextual contingency of appropriate leadership behavior (Oc, 2018).

This work has made an important contribution to the field by emphasizing the importance of followers' perceptions and expectations in the leadership process. As did Weber (1947, p.359) when he observed that charisma is about a leader being "regarded as of divine origin or as exemplary" (emphasis added), it recognizes that leadership is as much in the eye of the beholder as it is in the actions of the beheld (see also Nye \& Simonetta, 1996). But it goes further in recognizing that this is fundamentally a process of social categorization.

Yet as well as arguing that leaders need to be seen by others as leaders (and for those others to grant them the power to act as leaders; DeRue et al., 2009; Jiang et al., 2021), researchers have also argued that it is important for leaders to see themselves as leaders in order for them to be able to lead effectively (Day \& Halpin, 2007; DeRue \& Ashford, 2010; Zheng \& Muir, 2015). In particular, it has been observed that when (and to the extent that) a person identifies themselves as a leader - and this becomes integrated into their selfschema — they will be more motivated to act in a leader-like way (Day \& Lance, 2004; DeRue et al., 2009; Rus et al., 2010).

Research that expands on these ideas has explored the ways in which the internalization of leader identity makes a person more likely to claim, attain and maintain 
formal leadership roles (Day \& Halpin, 2004; Lord \& Hall, 2005; Middleton et al., 2019; Miscenko et al., 2017; Schyns et al., 2011). Amongst other things, it shows that once a person self-defines as a leader they may talk more authoritatively, project themselves more forcefully upon the world, and also be more willing to try out new leadership activities (e.g., by speaking out in meetings, taking responsibility for organizing events, putting themselves forward for awards and prizes; DeRue et al., 2009; Kempster, 2006). Research suggests, for example, that the pronounced willingness of men to take on leadership roles is one reason why women are often crowded out of them (Barreto et al., 2003) or can find themselves in suboptimal leadership positions (Ryan \& Haslam, 2007). By the same token, if women (are made to) experience conflict between gender identity and leader identity this can also hold them back in the workplace and beyond (Eagly \& Karau, 2002; Ibarra et al., 2013; Karelaia, \& Guillén, 2014; Heilman et al., 1989).

There is also evidence that taking on a leader identity can be a basis for metacompetencies which are important for leadership, including self-awareness, adaptability, and need for achievement (Day \& Dragoni, 2015; Hall, 2004; Tubbs \& Schulz, 2006). These high-order competencies can be understood to derive in part from leaders' desire to distinguish themselves and stand out from others, and to set themselves apart from, and above, potential followers (Hogg \& van Knippenberg, 2004; Steffens et al., 2022). But at the same time, it is apparent that these same motivations can sometimes lead individuals to pursue leadership in the service of their group (Lord \& Hall, 2005; Ramdass, 2022). This was seen, for example, when the French politician Alexandre Ledru-Rollin's observed (during the 1848 Revolution) that "I am their leader, I must follow them" (cited in Haslam et al., 2020, p.43).

Moreover, research suggests that leader identity can motivate individuals to take opportunities to develop and grow as a leader (e.g., by taking advantage or training and 
development opportunities; Ashford \& DeRue, 2012; Day, 2010; DeRue et al., 2009). There is evidence too that leader identity is positively associated with judgements of leader effectiveness made both by leaders themselves (Kragt \& Guenter, 2018) and by their superiors (Day \& Sin, 2011; Kwok et al., 2018; Miscenko et al., 2017; Peters \& Haslam, 2018a). Often, then, "looking like a leader" is an important part of the recipe for becoming one (Biermeier-Hanson, 2012; Ford et al., 2017; Todorov, 2017; Todorov et al., 2005; Truninger et al., 2020).

Together, these various strands of research have combined to make leader identity the focus of a burgeoning research field (as shown in Figure 1), particularly in the field of business and management. Indeed, in contrast to research on identity leadership (which, as Figure 2 shows, has had more pronounced impact in psychology and the social sciences) it is apparent that much of the impetus for growth here has derived from the fact that leader identity has been integral to a wide range of leader(ship) development programs. Not only, then, is leader identity something that is generally seen to be desirable, but it is also something that lends itself to focused training and coaching. This is all the more true because research suggests that people's sense of leader identity can be cultivated and strengthened through such activity (Chui, 2016; Day et al., 2009; Kwok et al., 2021).

Significant in this regard is work by Hammond and colleagues (2017) which points to ways in which particular development experiences contribute to increases in the strength, integration, level, and meaning of a person's leader-related sense of self. Importantly, these experiences can be acquired either through ongoing leadership activity or as a part of formal training that helps would-be leaders appreciate, develop and enact a strong, integrated and meaningful leader identity. Either way, the result of all this is that leaders not only develop a clear narrative of themselves as leaders (Ibarra \& Barbelescu, 2010; Zheng et al., 2020) but are also better equipped to live this out in the world. In effect, then, this work extends the 
Cartesian logic of cogito ergo sum (I think therefore I am) to the domain of leadership - so that the lesson becomes cogito sum princeps ergo sum (I think I am a leader therefore I am).

\section{Divergence in approaches to identity and leadership}

Having set out some of the key ideas associated with these two approaches to matters of identity and leadership, in this section we seek to tease out some of the key points of difference between them as these pertain to key aspects of the leadership process. Although some of these observations relate to points that have been explored and confirmed empirically, most reflect points of theoretical difference and hence we frame them as propositions (to be tested in future research) rather than as statements of fact. Moreover, our ultimate goal here is not to consolidate differences in perspective but rather to map out their distinct contributions our understanding of leadership so that we might be in a better position to make sense of — and ultimately reconcile — their divergent insights.

\section{Distinct leadership profiles}

As we have already observed, the most fundamental and obvious difference between work that focuses on identity leadership and that which focuses on leader identity is that whereas the latter views leadership as grounded in a leader's identity as an individual (their personal identity as 'me' and 'I'), the former views it as grounded in a psychological sense of group membership ('us-ness') that they share with other members of their ingroup (their social identity as 'one of us'). And although these constructs are not mutually exclusive (in ways that we will discuss later), they are not necessarily aligned. Accordingly, we propose that:

\section{P1. Leaders' identity leadership and leader identity (as perceived by leaders themselves} and by others) are distinguishable and independent from each other.

It should also be the case that identity leadership and leader identity impact social and organizational outcomes via different pathways and for different reasons. On the one hand, 
when leaders are motivated to act in the interests of their group (i.e., by engaging in identity leadership) this should in turn motivate other group members to display forms of creative followership necessary for the achievement of group goals (Haslam \& Platow, 2001). On the other hand, when leaders have a strong sense of leader identity they will often be motivated to act in stereotypically leader-like ways (Hains et al., 1997; Hogg et al., 1998). And although these will typically be focused more on the advancement of interests associated with personal identity than those associated with social identity (i.e., advancing 'me' rather than 'us'; Chatterjee \& Hambrick, 2007; Ellemers et al., 1999; Tyler \& Blader, 2003), under appropriate conditions they can nevertheless translate into positive group-level outcomes. We will discuss the nature of these conditions further below, but this is particularly likely to be the case in meritocratic systems that encourage and reward strategies of individual mobility but where there are nevertheless collaborative norms and high-level support for collaboration (Ellemers, 1993; Ellemers et al., 2004; Hogg \& Abrams, 1998; Tajfel \& Turner, 1979). Notwithstanding H1, we therefore propose that:

\section{P2. Both identity leadership and leader identity have the potential to contribute to} engagement-related organizational outcomes (e.g., organizational citizenship behavior), albeit via different psychological pathways.

P1 has rarely been subjected to a direct and focused test. However, before an intervention to build identity leadership, Haslam et al. (2017) found a very low correlation between leaders' motivations to engage in identity leadership and their motivations to enhance a sense of their own distinct identity as individual leaders $(r=.03)$. Moreover, after the intervention, there was a moderately strong negative correlation between these two constructs $(r=-.38)$.

There is, however, plenty of evidence, much of which we have alluded to already, that supports the distinct components of P2 (e.g., Day \& Sin, 2011; Steffens et al., 2018, 2021). 
Together, then, patterns of support for P1 and P2 suggest that, although they are independent, leader identity and identity leadership can be (and can become) more or less aligned as a function both of leaders' experiences and of the context in which they find themselves. This is a point that we can appreciate more clearly by reflecting on the processual distinctions between leader identity and identity leadership.

\section{Distinct leadership processes}

What then are the different pathways via which these two identity-based approaches to leadership operate? As outlined above, identity leadership is argued to work via processes that build and leverage leader's group-based ties to (potential) followers and thereby motivate those followers to contribute to the achievement of goals that are perceived to advance group interests. More specifically, SCT (Turner et al., 1987) suggests that leaders' capacity for influence is grounded in their capacity to create, advance, represent, and embed a sense of social identity — a sense of "us-ness" — that they share with followers. It is this "us-ness" that then provides a basis for them to achieve power through those followers (Haslam et al., 2011; Hogg, 2001; Steffens et al., 2014; Steffens \& Haslam, 2013; Turner, 2005). More formally, then, we propose that:

\section{P3. Identity leadership (and an emphasis on this; e.g., on the part of leaders within an} organization) will generally (a) reinforce the value and salience of a social identity that leaders share with followers, (b) be associated with efforts to bind leaders to the groups they lead, and in turn (c) contribute to leaders' influence-based impact (their 'power through'others).

In contrast, leader identity is argued to have impact by virtue of its capacity to motivate individuals to develop and advance their personal credentials and goals in a particular social and organizational setting (DeRue et al., 2009). As Day and Sin put it, leader identity "helps to ground individuals in terms of who they are, what their major goals and 
aspirations are (e.g., possible selves), and what their personal strengths and challenges are" (2012, p.547). In line with the "great man" logic upon which the field of leadership was founded (after Carlyle, 1840), efforts to build and promote leader identity thus envisage a world in which individual leaders come to the fore by virtue of their capacity to make a case (not least to themselves) for their superiority vis-a-vis other group members (Ashford \& DeRue, 201; Gemmill \& Oakley, 1992). Understood through the lens of SCT (Turner et al., 1987, 1994), on this basis we can propose that:

\section{P4. Leader identity (and an emphasis on this; e.g., on the part of leaders within an} organization) will generally (a) reinforce the salience of leaders' personal identity, (b) be associated with dynamics that differentiate leaders from the groups they lead, and in turn (c) contribute to leaders' resource-based impact (their 'power over' others).

P3 and P4 have not been directly tested in previous research. Nevertheless, they are consistent with the logic of much of the research that we have reviewed thus far, as well as the research that supports them. In particular, consistent with P3, there is evidence that activities which focus leaders on the need to build a sense of shared identity within the teams they lead serves to build their team identification (Haslam et al., 2017) and sense of collective efficacy (Slater \& Barker, 2019), and that these have similar impact on team members (Mertens et al., 2021a, 2021b). Elsewhere, support for P4 comes from a plethora of studies which point to the ways in which leaders' personal self-confidence and personal agency can be increased by their internalization of a sense of themselves as a leader (e.g., as reviewed by Ashford \& DeRue, 2012; Day \& Dragoni, 2015; Hammond et al., 2017).

In line with the logic of SCT, we can also understand the relationship between P3 and P4 (and their relationship to P1) by mapping the processes that are the focus of research on identity leadership and leader identity in two-dimensional space (in ways suggested by 
Epitropaki et al., 2017). This is seen in Figure 3 where one dimension is defined by differences in analytic/self focus and the other by the inclusivity of psychological analysis.

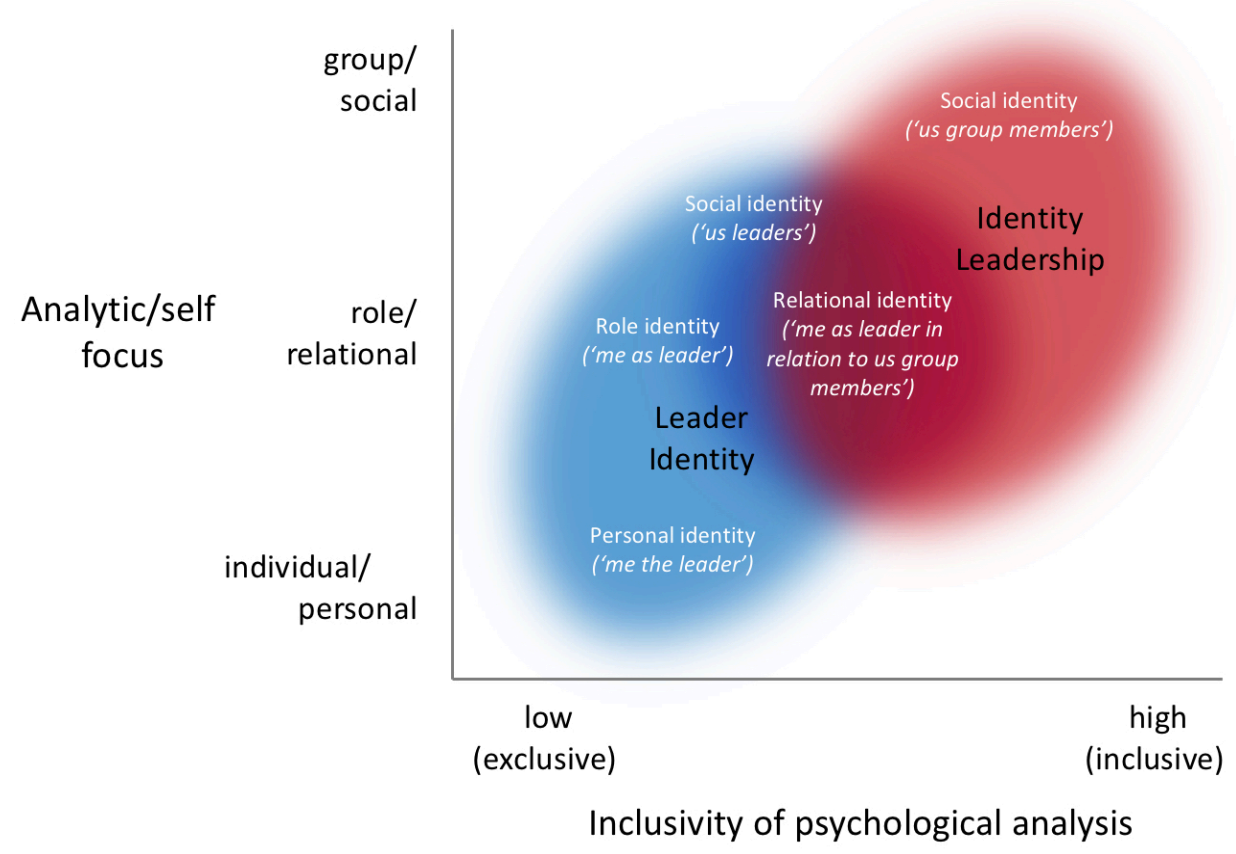

Figure 3 Differences in the analytic focus of (research on) leader identity and identity leadership.

This figure serves to reinforce three key points. The first of these is that identity leadership and leader identity entail a markedly different analytic focus for both researchers and would-be leaders. So whereas identity leadership focuses primarily on leadership and identity as group phenomena associated with a social self that is inclusive of others (e.g., Hogg, 2001; Turner \& Haslam, 2001), leader identity focuses on these things as primarily (inter)personal processes and phenomena associated with a personal self that is defined more exclusively (e.g., Ashford \& DeRue, 2012; Chan \& Drasgow, 2001; Lanaj et al., 2021). Second, within these two research traditions, there are specific forms of identity that also differ along these dimensions. For example, within the body of work on leader identity, researchers note that this sometimes operates as an identity that is unique to a specific 
individual (e.g., "me the leader"), but also sometimes as a social identity that is shared with others (e.g., "us leaders"; Ashford \& DeRue, 2012).

Third, it is apparent that rather than being entirely distinct, there is an area of overlap which defines an important point of contact between the two traditions. This overlap relates to contexts in which leaders are attuned to both their personal identity as a leader and the social identity they share with the team they lead. Here leadership is realized through a relational identity in which these two levels of analysis are articulated with each other - so that a leader's personal identity as a leader is grounded in their social identity as a member of a particular group and their role-related ties and relationships to other members of that group (e.g., in ways discussed by Day \& Dragoni, 2015; Brewer \& Gardner, 1996; Jolly et al., 2020*; Postmes \& Jetten, 2006; Rast et al., 2019; Sluss \& Ashforth, 2007; Sluss et al., 2011). Importantly, by virtue of its potential to galvanize the energies of both leader identity and identity leadership (e.g., as implied by P2), this point of contact has particularly important implications for leadership dynamics. Accordingly, this potential—and the factors that contribute either to its realization or to its suppression - is something we will return to reflect on in more detail below.

\section{Distinct leadership pathways}

Yet notwithstanding their points of contact, it is also the case that because concern for identity leadership and for leader identity entail very different foci, they should also take those who pursue them along quite different development pathways. More specifically, concern for leaders' identity leadership (on the part either of leaders themselves or of those who are interested in their development) should motivate leaders to gravitate towards the groups they are seeking to lead. However, this gravitational pull should be less apparent when leaders are concerned with the development of their leader identity. Indeed, here leaders may focus their efforts more on ensuring that they embody prototypical leadership 
characteristics (e.g., of a form discussed by Lord \& Maher, 1990; Lord et al., 2001) in the eyes of others outside the group — in particular, those who make formal assessments of these things (e.g., their own superiors, members of appointment committees).

To the extent that these different motivations are at work, depending on their concern for either leader identity or leadership identity, leaders may encounter divergent reactions from different parties. In the first instance, to the extent that leaders (seek to) engage in identity leadership this should be more likely to secure support for their leadership from fellow members of their ingroup (e.g., in ways observed by Barreto \& Hogg, 2017; Steffens et al., 2021; van Dick et al., 2018). However, reactions to their leadership should be less enthusiastic outside this ingroup, and in particular, their leadership credentials may be less likely to be recognized by external parties who assess their leadership. More formally, then, we propose that:

P5. The challenges of developing identity leadership will motivate would-be leaders to engage with the collective identity of the groups they seek to lead and this development will generally be more appealing to rank-and-file members of those groups than it is to external parties (e.g., those who occupy senior positions in an organization).

In contrast, when leaders are motivated to develop and promote their leader identity the resulting behaviour may be relatively uninspiring for other members of their ingroup but more likely to find favor among outsiders who assess their leadership in relation to generic leader prototypes. Here, then, we propose that:

P6. The challenges of developing a leader identity will not primarily motivate would-be leaders to engage with the collective identity of the groups they seek to lead and this development will generally be less appealing to rank-and-file members of those groups than it is to external parties (e.g., those who occupy senior positions in an organization). 
Again, these propositions have not hitherto been of any great interest to leadership researchers. Nevertheless, some support for them emerges from longitudinal research by Peters and Haslam (2018a, 2018b) which examined reactions to the leadership of elite military personnel as they progressed through an intensive training program designed to increase their capability as leaders. This found that whereas those in senior positions were attuned to, and rewarded, the positive aspects of trainees' leader identity (related to the fact that those trainees presented themselves to the world as leaders), their peers were more attuned to the positive consequences of their identity leadership (related to their perceived capacity to understand and advance ingroup interests). Accordingly, when it came to formally recognizing individuals' leadership prowess, team members were more likely to endorse those who cast themselves as group followers rather than leaders; however, the opposite was true for those in positions of command.

That said, it is unclear whether this is a pattern that would be replicated in other organizational contexts or in studies using a naturalistic causal design (Sieweke \& Santoni, 2020). It is unclear too what its implications are for broader aspects of group and organizational functioning. One might imagine, for example, that these two pathways would appeal to leaders with differing patterns of team and organizational identification, and that interest in supporting people's progress down these pathways (e.g., by procuring particular forms of leadership training) would also vary as a function of a person's ingroup-outgroup status in relation to the group that is being led. More generally, the issue of who buys into these different models of leadership and identity (and what exactly these entail) takes us to our next set of considerations.

\section{Distinct leadership products}

An obvious extension of the foregoing observations is that when researchers and practitioners are looking to assess and develop leadership, the tools they use for this purpose 
will differ markedly depending on whether their interest is in identity leadership or leader identity. More specifically, we can propose that:

\section{P7. Leader identity will generally lend itself to individual-focused activities and} interventions that assess and seek to develop the leader's personal identity as an individual.

While:

P8. Identity leadership will generally lend itself to group-focused activities and interventions that assess and seek to develop the leader's social identity as a group member.

When it comes to assessment, two measures are most widely used to capture these two forms of leadership and, as can be seen from Table 1, their content is very much in line with these propositions. On one hand, the Identity Leadership Inventory (ILI; Steffens et al., 2014) focuses on the four aspects of identity leadership that we discussed above (identity prototypicality, identity advancement, identity entrepreneurship, and identity impressarioship). This questionnaire has been validated in over 20 countries around the world (van Dick et al., 2018), and is typically used to explore (potential) followers' perceptions of a given leader's capacity to represent, advance, create and embed their group (e.g., as it is by Khumalo et al., 2022*, in this special issue).

On the other hand, the leader-self-identity scale (Hiller, 2005) has also been widely used and validated (e.g., by Day \& Sin, 2011) but it zeroes in on a leader's self-categorization as a leader-using items that are actually quite similar to those used by social identity theorists to assess self-categorization at a higher level of abstraction (e.g., such that "I see myself as a member of this group" becomes "I see myself as a leader"; Doosje et al., 1995; Ellemers et al., 1999; Postmes et al., 2013). Moreover, reflecting this difference in selfcategorical focus (and in line with H7), Steffens et al. (2022) found that leader identity was 
more strongly associated with leaders' striving to cultivate their personal identity as a leader $(r$ 's $=.68, .65, .64)$ than it was with their striving to cultivate collective identity around team members $(r$ 's $=.40, .32, .43)$. Note, though, that the latter relationships were still moderately strong. This finding speaks to the fact that, as we noted in discussing P2, developing a sense of leader identity is not necessarily inconsistent with the pursuit of identity leadership (Day \& Harrison, 2007).

Table 1. Measures of identity leadership and leader identity

The identity leadership inventory (ILI)* The leader self-identity scale \#

- This leader is a model member of [the group]. $\quad$ I I am a leader

- This leader acts as a champion for [the group]. • I see myself as a leader

- This leader creates a sense of cohesion within

- If I had to describe myself to others, I [the group]. would include the word 'leader'

- This leader creates structures that are useful for - I prefer being seen by others as a leader [group members]

Note: * The short-form version of the 15 -item scale developed by Steffens et al. (2014).

${ }^{\#}$ Scale developed by Hiller $(2005, \mathrm{p} .165)$

It also follows that efforts to train and develop leaders will have a very different focus depending on whether they are informed by a concern to develop leader identity or to develop identity leadership. In this regard, interventions to develop leader identity (either as a core or an incidental objective) typically have an emphasis on improving the skills and mindsets of individual leaders (Hay \& Hodgkinson, 2006; Middleton et al., 2019; Muir, 2014; Pyle, 2013; Zheng \& Muir, 2015). And while this can involve working with groups, this is not necessarily the case. In contrast, interventions to develop identity leadership generally make working with groups a priority (Fransen, Haslam et al., 2020; Haslam et al., 2017; Meertens et al., 2020, 2021; Slater \& Barker, 2019). 
Along the lines of points that we made in discussing P2, it seems likely too that the identity-related emphasis of leadership programs will have an impact not only on the personal and social motivations of those who take part in them (as observed by Haslam et al., 2017) but also on people's motivations to take part. Suggestive of the latter point, there is some evidence that the more a person is preoccupied with their own individuality (i.e., the more narcissistic they are), the more interested they will generally be in learning about traits associated with leader identity $(r=.26)$, but that this observation is somewhat less true when it comes to learning about identity leadership ( $r=.10$; Steffens \& Haslam, 2020).

Again, these matters are not a routine concern for leadership scholars. But perhaps they should be- - especially in light of growing concern about the capacity for the leadership industrial complex to attract and animate those whose ambitions are egotistical rather than altruistic (Alvesson, 2019; Brown, 2014; Chatterjee \& Hmbrick, 2007; Chaterjee \& Pollock, 2017; Collinson \& Tourish, 2015; Kellerman, 2012, 2016; Ladkin, 2020; Rosenthal \& Pittinsky, 2006; Tourish, 2013).

\section{Distinct leadership philosophies}

Consideration of the differential appeal of different approaches to questions of leadership and identity also alerts us to the fact that, at heart, these two approaches reflect different philosophies of leadership. More specifically, interest in leader identity can be seen to extend a traditional leader-centric view of the process in which narratives of success and progress are structured around an outstanding individual who is maximally different from others (after Carlyle, 1840). As Alvesson puts it, here: "The assumption is that the leader is very superior to everybody else. S/he knows best and ... is clearly the centre of the organizational universe" $(2019$, p.30). It follows, then, that this approach should have appeal in social and organizational contexts which embrace, and look to instantiate, an individualistic and meritocratic worldview. Moreover, the core tenets of SIT lead us to expect 
that this will generally be more true to the extent that systems (and those who lead them) place an emphasis on personal mobility as a means of self-enhancement (à la 'the American Dream'; Tajfel \& Turner, 1979; see also Ellemers \& Haslam, 2010; Hogg \& Abrams, 1988; Sandel, 2020). Accordingly, we propose that:

P9. An emphasis on leader identity will generally be more welcome in organizations and cultures that are individualistic and meritocratic and that embrace a philosophy of personal mobility.

At the same time, though, SIT also suggests that strategies of personal mobility will not always find favor, and that structural and psychological factors will sometimes combine to lead people to prioritize collective opportunities to achieve progress and change (Tajfel \& Turner, 1979). This desire for collective progress can come to the fore, for example, when avenues to personal self-enhancement are perceived to be limited and/or when socialstructural realities motivate people to instead work together to pursue opportunities for social creativity and social competition (Ashforth \& Kreiner, 1999; Tajfel \& Turner, 1979). Under these circumstances, we anticipate that identity leadership may be more appealing as a vehicle for enhancing collective self-efficacy and agency (Reicher et al., 2005). More formally, we propose that:

P10. An emphasis on identity leadership will generally be more welcome in organizations and cultures that are collectivistic and democratic and that embrace a philosophy of social creativity and/or social competition.

Neither of these propositions has previously been formally tested, and moreover there is little evidence that relates directly to them. Nevertheless, the fact that work on leader identity originates in, and continues to gain energy from, the relatively individualistic field of business and management (Bozeman, 2007; Van Hoorn, 2014; see Figure 2) can be seen to be consistent with P8, just as enthusiasm for identity leadership in fields of sport, the arts, 
health, and public service can be seen to be consistent with P9. As we noted above, it is telling too that, to date, all the published research on interventions that seek to build identity leadership has been conducted in contexts where advancement of the collective is at least as important as advancement of the individual.

Clearly, though, the question of whether and how philosophy and ideology inform passion for different approaches to identity and leadership is one that remains to be properly addressed. In particular, there would appear to be scope to explore the ways in which P9 and P10 relate not just to organizational differences but to individual differences (e.g., in 'dark triad' personality traits of narcissism, psychopathy and Machavellianism; Furtner et al. 2011). In this context we would note too, that by helping to shed light on the attractions of toxic leadership such research might help to address a significant—albeit slippery and perennially marginalized — question for the field of leadership as a whole (Alvesson, 2019; Gemmill \& Oakley, 1986; Lipman-Blumen, 2005, 2006; Mumford \& Fried, 2014). At the same time we would note that such research might also help to address calls for research into toxic leadership to lift its game both theoretically and empirically (Fischer et al., 2021). Attention to matters of identity may thus be one very powerful way of gaining traction on this question as a means of driving the field forward. Moreover, it is also worth asking whether in the context of pursuing this agenda progress might be made by seeking to develop an integrative framework that also reconciles the various other differences between identity leadership and leader identity that we have observed thus far. In drawing this review to a close, it is to this possibility that we now turn.

\section{Reconciling divergent approaches to identity and leadership: A dual-identity model of}

\section{leader development}

It is clear from the foregoing review that research on identity and leadership has developed in very distinct ways such that researchers who focus on the dynamics of leader 
identity have explored leader profiles, psychological processes, development pathways, practitioner products, and social and organizational philosophies that are generally very different from those explored by researchers interested in identity leadership. In itself this is unproblematic and indeed it can be seen as indication of the richness and diversity of leadership research (Antonakis et al., 2019). Yet in so far as the work in these two areas of leadership scholarship is ostensibly concerned with very similar things, the extent of their estrangement might nevertheless strike one as surprising. Accordingly, in this final section of our review we turn to the question of whether and how the two approaches might be brought into alignment.

In recent years, there have been a number of developments that give cause for optimism on this front. In the first instance, as Epitropaki et al. (2017) note, the two approaches not only have similar goals, but also work with similar constructs. In particular, both recognize the self as central to leaders' engagement in leadership and to the success of that engagement. Both also recognize that the self is a categorical structure that, in principle at least, can be defined at different levels of abstraction (Hogg, 2001; Lord \& Maher, 1990; Turner \& Haslam, 2001; after Rosch, 1978).

As work on leader identity progressed, researchers have also noted that the leader identity of leaders who are most effective and successful tends not to be focused entirely on their personal self but also to encompass relational and collective dimensions (Clapp-Smith et al., 2019; Day \& Harrison, 2007; Fleming et al., 2018; Jolly et al., 2020*; Johnson et al., 2012; Lord \& Hall, 2005). More particularly, Lord and Hall (2005), argue that forms of leader identity that are isomorphic with personal identity (such that leadership is all about 'me the leader') can be understood as relatively immature, and that with greater expertise and maturity leaders grow into more collective aspects of identity, such that "as leaders develop, there is a shift in focus from individual to collective-level identities, both for the leader's own 
self-identity, and the identities of the followers" (p.596; see also Johnson et al., 2012; Komives et al., 2005). Likewise, Day and Harrison (2007) argue that "a cadre of highly developed individual leaders" will be poorly suited to complex challenges of leadership and that overcoming these instead requires leaders with "shared, distributed, collective, or connected leadership capacity" (2007, p.362).

Coming at related issues from a social identity perspective, in recent years researchers have noted that having a strong sense of social identity is not necessarily inconsistent with having a strong sense of personal identity. Early statements of SCT suggested that as a consequence of the principle of functional antagonism there might be a hydraulic relationship between these two levels of self-categorization whereby as one increases the other declines (Turner et al., 1987). However, as this idea was put to empirical test, researchers increasingly questioned this principle (Postmes \& Jetten, 2006). Not least, this was because it became clear that there are a range of contexts in which people's personal identity comes to be defined more or less exclusively by their social identity (Baray et al., 1999) — a process researchers refer to as identity fusion (Swann et al., 2012). This can be understood as a form of very high social identification in which the line between personal identity ('me') and social identity ('us') is hard to discern — potentially because it no longer exists.

More generally, this phenomenon speaks to evidence that people can simultaneously self-categorize at multiple levels of abstraction (e.g., as members of a subgroup and of a superordinate group) and that, when they do, this dual identification is associated with distinctive forms of social and organizational behavior (Eggins et al., 1999; Harquail \& King, 2003; Hornsey \& Hogg, 2000; Thomas et al, 2009). In this vein, Haslam et al. (2003) and Hogg and Terry (2000) discuss a range of ways in which multi-level identities contribute to - and often prove to be essential for - complex forms of high-level organizational behavior including multi-party negotiation, participative goal-setting and strategic planning. A key 
point here is that optimal outcomes are unlikely to be achieved unless leadership is sensitive to all of the identity concerns (of both leaders and followers) that bear upon a given issue. This assertion is grounded in the observation when organizational process and policy is blind to the identities that matter to people it generally fails to engage their energies (or, when it does, it engages them in counterproductive ways; Humphreys \& Brown, 2002; Jetten et al., 2002).

In much the same way, one can argue that leader-group identity fusion contributes to distinctive forms of leadership in which the leader has a strong sense of their personal identity as a leader but this is grounded in, and emerges from, an equally strong sense of social identity that they share with fellow ingroup members (and for whom they feel obligation and responsibility; e.g., along lines discussed by Scholl et al., 2018; Yaffe \& Kark, 2011). This fusion is represented schematically in Figure 4 as the intersection between leader identity and identity leadership. Examples of its phenomenology in the world at large can be found in Nelson Mandela's observation that "I have always regarded myself, in the first place, as an African patriot" and in Theodore Roosevelt's claim that "I am, if I am anything, an American. I am an American from the crown of my head to the soles of my feet" (cited in Haslam \& Reicher, 2016, p.21). Critically, then, here the leader's identity as both leader and group member allows them to mobilize the resources of both personal and social identity. More specifically, the former should motivate them to project themselves onto the world and to engage in leader-like activities (e.g., in ways suggested by Ashford \& DeRue, 2012; Day, 2010; DeRue et al., 2009) at the same time that the latter should ensure that these are informed by, and help to advance, the interests of their group (e.g., in ways suggested by Chrobot-Mason et al., 2016; Haslam et al., 2020; Hogg et al., 2012a; Steffens et al., 2014). On this basis, then, we can propose that: 
P11. Leadership will be more effective to the extent that leader-group identity fusion brings the demands of leader identity into alignment with the demands of identity leadership. Similarly, we can hypothesize that efforts to develop leadership (e.g., through training and coaching) will be more effective to the extent that they support this process of leader-group identity fusion.

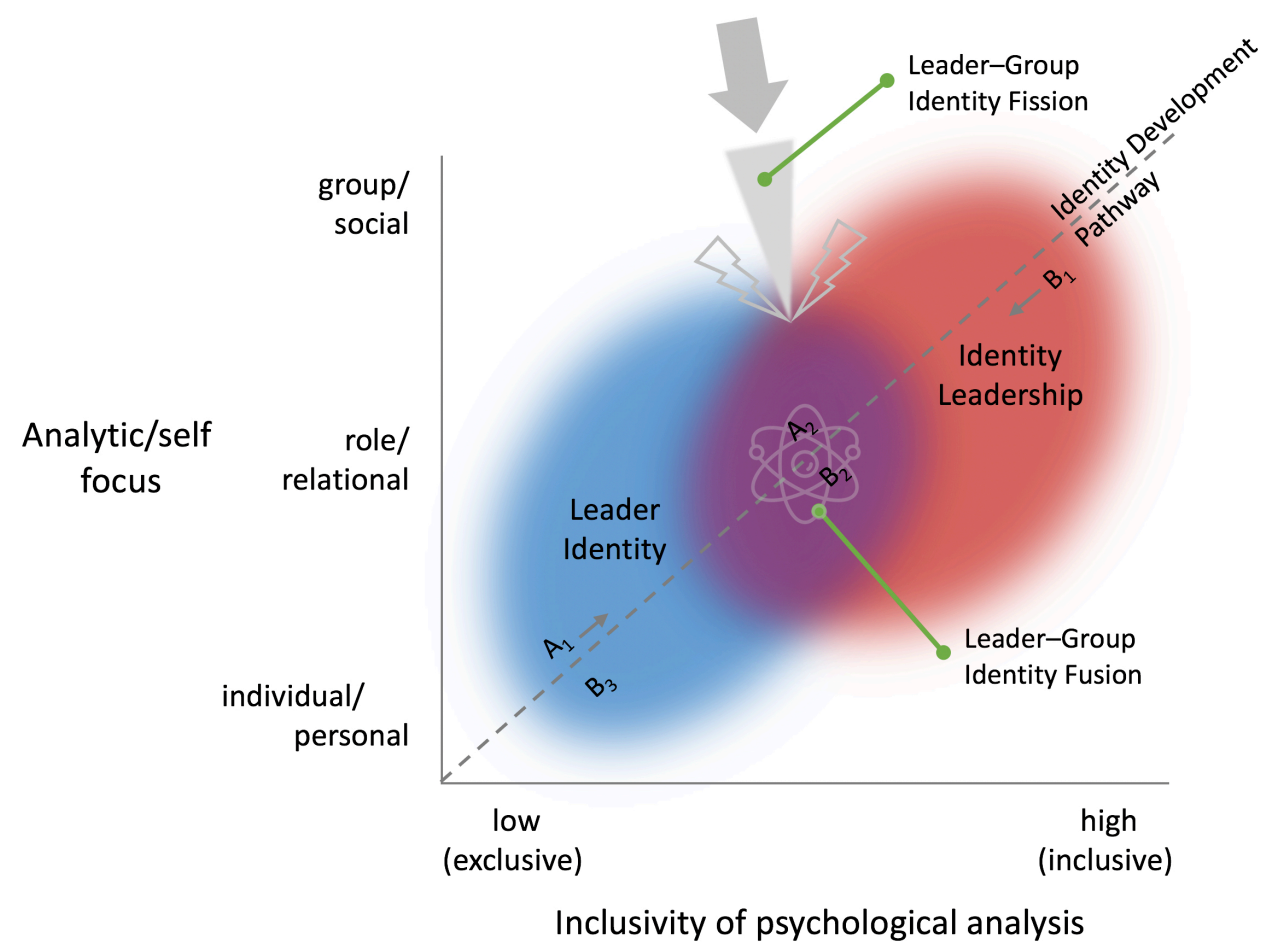

Figure 4 Leader-group identity fusion and leader-group identity fission.

Note: Leader-group identity fusion has an integrative impact on the energies of leader identity and identity leadership. Leader-group identity fission has a disintegrative impact on those same energies.

Again, this proposition has not been formally tested. However, it is consistent with the developmental trajectories described by Lord and Hall (2005) and Day and Harrison (2007) and with evidence that we discussed earlier which suggests that although leader identity and identity leadership are distinct constructs (as per P1) they can be brought into alignment in ways that allow both to contribute to positive engagement-related outcomes (as per P2; see Antonakis et al., 2011). Indeed, conceptually, one can understand the 
developmental trajectory here as movement towards leader-group identity fusion along the plane from $A_{1}$ to $A_{2}$ described in Figure 4.

However, it is important to acknowledge that there is nothing inevitable about leaders' progression towards a state of leader-group identity fusion. So although many leaders will have this developmental trajectory, many others will not. Whatever the sphere of activity (e.g., whether politics, business or academia), the world is replete with leaders whose desire to advance their leader identity has increasingly compromised their capacity to do identity leadership. Indeed, Haslam et al. (2011) suggest that, if anything, this may be the more typical progression. This is because leaders easily fall prey to the "leader trap" (that we might more accurately call the leader identity trap) of initially succeeding as leaders by mobilizing their group through identity leadership but ultimately failing because they neglect the group or take it for granted. Here, then, the developmental trajectory is one where leadergroup identity fusion (as leaders move along a plane from $\mathrm{B}_{1}$ to $\mathrm{B}_{2}$ in Figure 4) ultimately gives way to leader-group identity fission (as they move from $\mathrm{B}_{2}$ to $\mathrm{B}_{3}$ ). Here, then, we propose that:

P12. Leadership will be less effective to the extent that leader-group identity fission brings the demands of leader identity into conflict with the demands of identity leadership.

In the world at large there are a range of factors that can contribute to this fission. One is leaders' hubris (Kroll et al., 2000; Petit \& Bollaert, 2012). Certainly, if one succeeds as a leader by harnessing the power of the group it can be tempting to succumb to the romantic attributional error of assuming that this was all one's own work (Berger et al., 2020). However, in organizations and society at large there are also structural forces that encourage such attributions and thereby drive a wedge between leader identity and identity leadership. For example, there are appraisal systems and reward structures that require people to 
privilege the individual over the collective (Van Hoorn, 2014; Waring, 1999). There are also societal narratives and practices that persistently reinforce heroic understandings of the leadership process (Gemmill \& Oakley, 1992). Moreover, on top of this, the enemies of a group may seek to inflame intragroup tension by alerting rank-and-file group members to the leader's laurels in ways that weaken their identity-based ties to that leader and the group (Maskor et al., 2021).

These various reflections alert us to the fact that leadership and identity never manifest themselves in a vacuum. Moreover, the organizations and groups in which they arise are never monocultures devoid of texture or choice. Importantly too, although leader-group identity fusion will tend to make groups and leadership more effective, there is no sense in which this fusion is, in itself, a 'better' process than that of identity fission. Indeed, within the social psychological literature, considerations of identity fusion often come with a health warning on account of the fact that this process is generally associated with high levels of commitment to a group of a form that can shade into fanaticism (Baray et al., 2009; Swann et al., 2009).

This same health warning can sometimes also be warranted in the domain of leadership — noting that whereas above we cited Roosevelt and Mandela as positive exemplars of leader-group identity fusion, we could also point to Hitler's claim that “Above all, I am a German. As a German I feel at one with the fate of my people" as a manifestation of essentially the same process (Reicher \& Haslam, 2016, p.21; see also Galvin et al., 2015). Here, then, we would not want to bring leader identity and identity leadership into alignment but rather to tear them asunder. This observation in turn alerts us to the fact that when it comes to practical matters of leadership, identity content is at least as important as identity process (Galvin et al., 2015; Haslam et al., 2011; Rast et al., 2019). So although there often is a general tendency in leadership research to see leadership as an unalloyed good (Alvesson et 
al., 2016), its value for society ultimately depends on the values and norms by which groups and their members are animated.

\section{Conclusion}

Absolute identity with one's cause is the first and great condition of successful leadership (Woodrow Wilson, cited in Pestritto, 2005, p.214)

We noted at the outset that research into leadership and identity has hitherto been associated with two divergent streams of activity. One of these focuses on the leader's personal identity as an individual, the other on their social identity as a member of a group or collective. Yet although it is clear that these have lent themselves to very different ways of thinking about the leadership process, we also suggested that there is a possibility of a rapprochement between them that brings the theory and practice of identity leadership and leader identity into alignment. More specifically, we argued that leaders will be best placed to lead effectively when their identity as leaders is founded upon, and hence intrinsically compatible with, their identity as group members. This indeed is the "first and great condition of successful leadership" to which Wilson alludes.

At a deeper level, though, we can see that Wilson's observation alerts us to the fact that in order to lead one also has to have a cause - in other words, a group of some form that one is looking to represent and advance. It is for this reason, that, on its own, leader identity is of little practicable use. Nevertheless, when harnessed to a group and a social identity, it can be a potent force.

This is a point that is brought home in different ways by many of the papers in this special issue (notably Khumalo et al., 2022*; Selvanathan et al., 2022*). We see too that it is only when leaders bring their personal and social identities into alignment that they are able to mobilize the power of the group to change the world. This mobilization can be, but is not 
always, collectively enriching. Yet as Wilson opined elsewhere, if leaders fail to do this, their leadership will always be impoverished (Hart, 2002, p.15). 


\section{References}

* = paper included in this special issue

Akerlof, G. (2020). The social identity approach to leadership and why it matters. Foreword to S. A. Haslam, S. D. Reicher, \& M. J. Platow. The new psychology of leadership: Identity, influence and power (2nd ed., pp xvi-xx). Routledge.

Alvesson, M. (2019). Waiting for Godot: Eight major problems in the odd field of leadership studies. Leadership, 15, 27-43.

Alvesson, M., Blom, M., \& Sveningsson, S. (2016). Reflexive leadership: Organising in an imperfect world. Sage.

Alvesson, M., \& Einola, K. (2019). Warning for excessive positivity: Authentic leadership and other traps in leadership studies. The Leadership Quarterly, 30, 383-395.

Antonakis, J., Banks, G. C., Bastardoz, N., Cole, M. S., Day, D. V., Eagly, A. H., ... \& Weber, R. (2019). Leadership Quarterly: The State of the Journal. The Leadership Quarterly, 30, 1-9.

Antonakis, J., d'Adda, G., Weber, R. A., \& Zehnder, C. (2021). Just words? Just speeches? On the economic value of charismatic leadership. Management Science. Advance online publication. https://doi.org/10.1287/mnsc.2021.4219.

Antonakis, J., Fenley, M., \& Liechti, S. (2011). Can charisma be taught? Tests of two interventions. The Academy of Management Learning and Education, 10(3), 374-396.

Ashford, S. J., \& DeRue, D. S. (2012). Developing as a leader: The power of mindful engagement. Organizational Dynamics, 41, 146-154.

Ashforth, B. E., \& Kreiner, G. E. (1999). "How can you do it?”: Dirty work and the challenge of constructing a positive identity. Academy of management Review, 24, 413-434.

Ashforth, B. E., \& Mael, F. (1989). Social identity theory and the organization. Academy of Management Review, 14, 20-39.

Avolio, B. J. (2007). Promoting more integrative strategies for leadership theory-building. American Psychologist, 62, 25-33.

Baray, G., Postmes, T., \& Jetten, J. (2009). When I equals we: Exploring the relation between social and personal identity of extreme right-wing political party members. British Journal of Social Psychology, 48, 625-647.

Barreto, M., Ryan, M. K., \& Schmitt, M. (Eds.) (2009). Barriers to diversity: The glass ceiling in the 21st century. APA Books.

Barreto, N. B., \& Hogg, M. A. (2017). Evaluation of and support for group prototypical 
leaders: A meta-analysis of twenty years of empirical research. Social Influence, 12, 41 55.

Bennis, W. (1999). The end of leadership: Exemplary leadership is impossible without full inclusion, initiatives, and cooperation of followers. Organizational Dynamics, 28, 71-80.

Barentsen, J. (2015). Church leadership as adaptive identity construction in a changing social context. Journal of Religious Leadership, 15, 49-80.

Berger, J., Osterloh, M., Rost, K., \& Ehrmann, T. (2020). How to prevent leadership hubris? Comparing competitive selections, lotteries, and their combination. The Leadership Quarterly, 31, 101388.

Biermeier-Hanson, B. (2012). Looking like a leader: An investigation into racial biases in leader prototypes. Wayne State University.

Bozeman, B. (2007). Public values and public interest: Counterbalancing economic individualism. Georgetown University Press.

Brewer, M. B. (1991). The social self: On being the same and different at the same time. Personality and Social Psychology Bulletin, 17, 475-482.

Brewer, M. B., \& Gardner, W. (1996). Who is this" We"? Levels of collective identity and self representations. Journal of Personality and Social Psychology, 71, 83-93.

Brown, A. (2014). The myth of the strong leader: Political leadership in the modern age. London: Bodley Head.

Carlyle, T. (1840). Heroes and hero worship. London: Harrap. p.5

Chan, K. Y., \& Drasgow, F. (2001). Toward a theory of individual differences and leadership: Understanding the motivation to lead. Journal of Applied Psychology, 86, $481-498$.

Chatterjee, A., \& Hambrick, D. C. (2007). It's all about me: Narcissistic chief executive officers and their effects on company strategy and performance. Administrative Science Quarterly, 52, 351-386.

Chatterjee, A., \& Pollock, T. G. (2017). Master of puppets: How narcissistic CEOs construct their professional worlds. Academy of Management Review, 42(4), 703-725.

Chui, S. L. M. (2016). Leader identity construction at social enterprises: Effects of social feedback, identity level, work role salience and organizational context. Unpublished doctoral dissertation, Durham University Business School.

Chrobot-Mason, D., Gerbasi, A., \& Cullen-Lester, K.L. (2016). Predicting leadership relationships: The importance of collective identity. The Leadership Quarterly, 27, 298- 
311.

Clapp-Smith, R., Hammond, M. M., Lester, G. V., \& Palanski, M. (2019). Promoting identity development in leadership education: A multidomain approach to developing the whole leader. Journal of Management Education, 43, 10-34.

Collinson, D., \& Tourish, D. (2015). Teaching leadership critically: New directions for leadership pedagogy. Academy of Management Learning \& Education, 14, 576-594.

Crano, W. D., \& Gaffney, A. M. (2021). Minority influence and leadership processes in the rise and fall of populist movements. In J. P. Forgas, K. Fiedler, \& W. D. Crano (Eds.) The psychology of populism: The tribal challenge to liberal democracy. Taylor \& Francis.

Day, D. V. (2010). The difficulties of learning from experience and the need for deliberate practice. Industrial and Organizational Psychology, 3, 41-44.

Day, D. V., \& Dragoni, L. (2015). Leadership development: An outcome-oriented review based on time and levels of analyses. Annual Review of Organizational Psychology and Organizational Behavior, 2, 133-156.

Day, D. V., \& Halpin, S. M. (2004). Growing leaders for tomorrow: An introduction. In D. V. Day, S. J. Zaccaro, \& S. M. Halpin (eds.), Leader development for transforming organizations: Growing leaders for tomorrow (pp. 3-22). Routledge.

Day, D. V. \& Harrison, M. M. (2007). A multilevel, identity-based approach to leadership development. Human Resource Management Review, 17, 360-373.

Day, D. V., \& Lance, C. E. (2004). Understanding the development of leadership complexity through latent growth modeling. In D. V. Day, S. J. Zaccaro, \& S. M. Halpin (Eds.), Leader development for transforming organizations: Growing leaders for tomorrow (pp. 41-69). Lawrence Erlbaum

Day, D. V., \& Sin, H. P. (2011). Longitudinal tests of an integrative model of leader development: Charting and understanding developmental trajectories. The Leadership Quarterly, 22, 545-560.

DeRue, D. S., \& Ashford, S. J. (2010). Who will lead and who will follow? A social process of leadership identity construction in organizations. Academy of Management Review, 35, 627-647.

DeRue, D. S., Ashford, S. J., \& Cotton, N. C. (2009). Assuming the mantle: Unpacking the process by which individuals internalize a leader identity. In L.M. Roberts \& J.E. Dutton (eds.), Exploring positive identities and organizations: Building a theoretical and research foundation (pp. 217-236). Routledge.

Doosje, B., Ellemers, N., \& Spears, R. (1995). Perceived intragroup variability as a function 
of group status and identification. Journal of Experimental Social Psychology, 31, 410436.

Eagly, A. H., \& Karau, S. J. (2002). Role congruity theory of prejudice toward female leaders. Psychological Review, 109, 573-598.

Eggins, R. A., Haslam, S. A., \& Reynolds, K. J. (2002). Social identity and negotiation: Subgroup representation and superordinate consensus. Personality and Social Psychology Bulletin, 28, 887-899.

Ellemers, N. (1993). The influence of socio-structural variables on identity enhancement strategies. European Review of Social Psychology, 4, 27-57.

Ellemers, N., De Gilder, D., \& Haslam, S. A. (2004). Motivating individuals and groups at work: A social identity perspective on leadership and group performance. Academy of Management Review, 29, 459-478.

Ellemers, N., \& Haslam, S. A. (2012). Social identity theory. In P. Van Lange, A. Kruglanski, \& T. Higgins (Eds.), Handbook of theories of social psychology (pp.379398). Sage.

Ellemers, N., Kortekaas, P., \& Ouwerkerk, J.W. (1999). Self-categorization, commitment to the group and group self-esteem as related but distinct aspects of social identity. European Journal of Social Psychology, 29, 371-389.

Elsbach, K. D., \& van Knippenberg, D. (2020). Creating high-impact literature reviews: An argument for 'integrative reviews'. Journal of Management Studies, 57, 1277-1289.

Epitropaki, O., Kark, R., Mainemelis, C., \& Lord, R.G. (2017). Leadership and followership identity processes: A multilevel review. The Leadership Quarterly, 28, 104-129.

Esler, P. (2021). 2 Corinthians: A social identity commentary. Bloomsbury Publishing.

Fischer, T., Hambrick, D. C., Sajons, G. B., \& Van Quaquebeke, N. (2020). Beyond the ritualized use of questionnaires: Toward a science of actual behaviors and psychological states. The Leadership Quarterly, 31(4), 101449.

Fischer, T., Tian, A. W., Lee, A., \& Hughes, D. J. (2021). Abusive supervision: A Systematic review and fundamental rethink. The Leadership Quarterly, 101540.

Fleishman, E. A. (1995). Consideration and structure: Another look at their role in leadership research. In F. Dansereau, \& F. J. Yammarino, (Eds.) Leadership: The multiple-level approaches (pp. 51-60). JAI Press.

Fleming, K., Millar, C., \& Culpin, V. (2018). From hollow hero to expert empathiser: Leadership in transition. Journal of Management Development, 37, 606-612.

Ford, J., Harding, N. H., Gilmore, S., \& Richardson, S. (2017). Becoming the leader: 
Leadership as material presence. Organization Studies, 38, 1553-1571.

Fransen, K., Haslam, S. A., Steffens, N. K., Peters, K., Mertens, N., Mallett, C. J., \& Boen, F. (2020). All for us and us for all: Introducing the 5R Shared Leadership Program. Psychology of Sport \& Exercise, 51, 101762.

Fransen, K., Haslam, S. A., Steffens, N. K., Vanbeselaere, N., De Cuyper, B., \& Boen, F. (2015). Believing in 'us': Exploring leaders' capacity to enhance team confidence and performance by building a sense of shared social identity. Journal of Experimental Psychology: Applied, 121, 89-100.

Fransen, K., McEwan, D., \& Sarkar, M. (2020). The impact of identity leadership on team functioning and well-being in team sport: Is psychological safety the missing link? Psychology of Sport and Exercise, 51, 101763.

Fransen, K., Steffens, N. K., Haslam, S. A., Vanbeselaere, N., De Cuyper, B., \& Boen, F. (2016). We will be champions: Leaders' confidence in 'us' inspires team members' team confidence and performance. Scandinavian Journal of Medicine and Science in Sports, $26,1455-1469$.

Furtner, M. R., Rauthmann, J. F., \& Sachse, P. (2011). The self-loving self-leader: an examination of the relationship between self-leadership and the dark triad. Social Behavior and Personality, 39, 369-379.

Gaffney, A. M., Rast III, D. E., \& Hogg, M. A. (2018). Uncertainty and influence: The advantages (and disadvantages) of being atypical. Journal of Social Issues, 74(1), 20-35.

Gaffney, A. M., Rast III, D. E., Hackett, J. D., \& Hogg, M. A. (2014). Further to the right: Uncertainty, political polarization and the American "Tea Party" movement. Social Influence, 9, 272-288.

Gaffney, A. M., Sherburne, B., Hackett, J. D., Rast III, D. E., \& Hohman, Z. P. (2019). The transformative and informative nature of elections: Representation, schism, and exit. British Journal of Social Psychology, 58, 88-104.

Galvin, B. M., Lange, D., \& Ashforth, B. E. (2015). Narcissistic organizational identification: Seeing oneself as central to the organization's identity. Academy of Management Review, 40(2), 163-181.

Gemmill, G., \& Oakley, J. (1992). Leadership: An alienating social myth? Human Relations, $45,113-129$.

*Giannella, V. A., Pagliaro, S., \& Barreto, M. (2022). Leader's morality, prototypicality, and followers' reactions. Leadership Quarterly,

Giessner, S. R., van Knippenberg, D., van Ginkel, W., \& Sleebos, E. (2013). Team-oriented 
leadership: The interactive effects of leader group prototypicality, accountability, and team identification. Journal of Applied Psychology, 98, 658-667.

Gunter, H., \& Rayner, S. (2020). The 'next big thing': A delineation of 'fads' and 'fashions'. The Palgrave handbook of educational leadership and management discourse (pp.1-17). Palgrave.

Hains, S. C., Hogg, M. A., \& Duck, J. M. (1997). Self-categorization and leadership: Effects of group prototypicality and leader stereotypicality. Personality and Social Psychology Bulletin, 23, 1087-1099.

Halevy, N., Berson, Y., \& Galinsky, A. D. (2011). The mainstream is not electable: When vision triumphs over representativeness in leader emergence and effectiveness. Personality and Social Psychology Bulletin, 37, 893-904.

Hall, D. T. (2004). Self-awareness, identity, and leader development. In D. Day, S. J. Zaccaro, S. M. Halpin (Eds.) Leader development for transforming organizations (pp. 173-196). Psychology Press.

Hammond, M., Clapp-Smith, R., \& Palanski, M. (2017). Beyond (just) the workplace: A theory of leader development across multiple domains. The Academy of Management Review, 42, 481-498.

Harquail, C. V., \& King, A. W. (2003). Organizational identity and embodied cognition: A multi-level conceptual framework. Academy of Management Proceedings, 2003, e1-e6.

Hart, A. B. (Ed.). (2002). Selected addresses and public papers of Woodrow Wilson. Boni and Liveright. (Originally published 1918).

Haslam, S. A. (2001). Psychology in organizations: The social identity approach ( $\left.{ }^{\text {st }} \mathrm{Ed}\right)$. Sage (2nd Ed., 2004).

Haslam, S. A. Eggins, R. A., \& Reynolds, K. J. (2003). The ASPIRe model: Actualizing Social and Personal Identity Resources to enhance organizational outcomes. Journal of Occupational and Organizational Psychology, 76, 83-113.

Haslam, S. A., Fransen, K., \& Boen, F. (Eds.) (2020). The new psychology of sport and exercise: The social identity approach. Sage.

Haslam, S. A., \& Platow, M. J. (2001). The link between leadership and followership: How affirming a social identity translates vision into action. Personality and Social Psychology Bulletin, 27, 1469-1479.

Haslam, S. A., \& Reicher, S. D. (2016). Rethinking the psychology of leadership: From personal identity to social identity. Daedalus, 145(3), 21-34. 
Haslam, S. A., Reicher, S. D., \& Platow, M. J. (2011). The new psychology of leadership: Identity, influence and power (1st Ed). London and New York: Psychology Press. (2nd Ed., 2020)

Haslam, S. A., Reicher, S. D. \& Platow, M. J. (2015) Leadership. In J. D. Wright (Ed.) International Encyclopedia of the Social and Behavioral Sciences (2nd Ed, pp. 648-654). Oxford, UK: Elsevier.

Haslam, S. A., Reicher, S. D., \& Van Bavel, J. J. (2019). Rethinking the nature of cruelty: The role of identity leadership in the Stanford Prison Experiment. American Psychologist, $74,809-822$.

Haslam, S. A., Steffens, N. K., \& Peters, K. (2019). The importance of creating and harnessing a sense of 'us': Social identity as the missing link between leadership and health. In R. Williams, V. Kemp, S. A. Haslam, C. Haslam, K. S. Bhui, \& S. Bailey (Eds.), Social scaffolding: Applying the lessons of contemporary social science to health, public mental health and healthcare (pp.302-311). Cambridge University Press.

Haslam, S. A., Steffens, N. K., Peters, K., Boyce, R.A., Mallett, C. J., \& Fransen, K. (2017). A social identity approach to leadership development: The 5R program. Journal of Personnel Psychology, 16, 113-124.

Hay, A., \& Hodgkinson, M. (2006). Rethinking leadership: A way forward for teaching leadership? Leadership \& Organization Development Journal, 27, 144-158.

Halevy, N., Berson, Y., \& Galinsky, A. D. (2011). The mainstream is not electable: When vision triumphs over representativeness in leader emergence and effectiveness. Personality and Social Psychology Bulletin, 37, 893-904.

Heilman, M. E., Block, C. J., Martell, R. F., \& Simon, M. C. (1989). Has anything changed? Current characterizations of men, women, and managers. Journal of Applied Psychology, 74, 935-942.

Hiller, N. J. (2005). Understanding leadership beliefs and leadership self-identity: Constructs, correlates, and outcomes. Dissertation Abstracts International: Section B: The Sciences and Engineering, 66(12-B), 6959.

Hogg, M. A. (2001). A social identity theory of leadership. Personality and Social Psychology Review, 5, 184-200.

Hogg, M. A. (2015). Constructive leadership across groups: How leaders can combat prejudice and conflict between subgroups. Advances in Group Processes, 32, 177-207.

Hogg, M. A. (2007). Uncertainty-identity theory. Advances in Experimental Social Psychology, 39, 69-126. 
Hogg, M. A. (2021). Self-uncertainty and group identification: Consequences for social identity, group behavior, intergroup relations, and society. Advances in Experimental Social Psychology, 64, 263-316.

Hogg, M. A., \& Abrams, D. (1988). Social identifications: A social psychology of intergroup relations and group processes. London: Routledge.

Hogg, M. A., Hains, S. C., \& Mason, I. (1998). Identification and leadership in small groups: Salience, frame of reference, and leader stereotypicality effects on leader evaluations. Journal of Personality and Social Psychology, 75, 1248-1263.

Hogg, M. A., \& van Knippenberg, D. (2004). Social identity and leadership processes in groups. Advances in Experimental Social Psychology, 35, 1-52.

Hogg, M. A., van Knippenberg, D., \& Rast, III D.E. (2012a). The social identity theory of leadership: Theoretical origins, research findings, and conceptual developments. European Review of Social Psychology, 23, 258-304.

Hogg, M. A., Van Knippenberg, D., \& Rast, D. E. III. (2012b). Intergroup leadership in organizations: Leading across group and intergroup boundaries. Academy of Management Review, 37, 232-255.

Hogg, M. A., \& Terry, D. J. (2000). Social identity and self-categorization processes in organizational contexts. Academy of Management Review, 25, 121-140.

Hogg, M. A., \& Turner, J. C. (1987). Intergroup behaviour, self-stereotyping and the salience of social categories. British Journal of Social Psychology, 26, 325-340.

Hogg, M. A., Turner, J. C., \& David, B. (1990). Polarized norms and social frames of reference: A test of the self-categorization theory of group polarization. Basic and Applied Social Psychology, 11, 77-100.

Hollander, E. P. (1992). The essential interdependence of leadership and followership. Current Directions in Psychological Science, 1, 71-75.

Hornsey, M. J., \& Hogg, M. A. (2000). Assimilation and diversity: An integrative model of subgroup relations. Personality and Social Psychology Review, 4, 143-156.

House, R., Javidan, M., Hanges, P., \& Dorfman, P. (2002). Understanding cultures and implicit leadership theories across the globe: An introduction to project GLOBE. Journal of World Business, 37, 3-10.

Humphreys, M., \& Brown, A. D. (2002). Narratives of organizational identity and identification: A case study of hegemony and resistance. Organization Studies, 23, 421447.

Ibarra, H., \& Barbulescu, R. 2010. Identity as narrative: Prevalence, effectiveness, and 
consequences of narrative identity work in macro work role transitions. Academy of Management Review, 35, 135-154.

Ibarra, H., Wittman, S., Petriglieri, G., \& Day, D. V. (2014). Leadership and identity: An examination of three theories and new research directions. In Day, D.V. (Ed), The Oxford handbook of leadership and organizations (pp. 289-305). Oxford University Press.

Ibarra, H., Ely, R., \& Kolb, D. (2013). Women rising: The unseen barriers. Harvard Business Review, 91(9), 60-66.

Jetten, J., Fielding, K., Mols, F., Crimston, C. \& Haslam, S. A. (2021). Responding to climate change disaster: The case of the 2019/2020 bushfires in Australia. European Psychologist, 26, 161-171.

Jetten, J., O’Brien, A., \& Trindall, N. (2002). Changing identity: Predicting adjustment to organizational restructure as a function of subgroup and superordinate identification. British Journal of Social Psychology, 41, 281-298.

Jiang, X., Snyder, K., Li, J., \& Manz, C. C. (2021). How followers create leaders: The impact of effective followership on leader emergence in self-managing teams. Group Dynamics: Theory, Research, and Practice. Advance online publication. https://doi.org/10.1037/gdn0000159

Johnson, R. E., Venus, M., Lanaj, K., Mao, C., \& Chang, C. H. (2012). Leader identity as an antecedent of the frequency and consistency of transformational, consideration, and abusive leadership behaviors. Journal of Applied Psychology, 97, 1262-1272.

*Jolly, P. M., Krylova, K. O., \& Phillips, J. S. (2020). Leader intention, misconduct and damaged relational follower identity: A moral decision making perspective. The Leadership Quarterly, 101425.

Judge, T. A., Piccolo, R. F., \& Ilies, R. (2004). The forgotten ones? The validity of consideration and initiating structure in leadership research. Journal of Applied Psychology, 89, 36-51.

Kark, R., \& Van Dijk, D. (2007). Motivation to lead, motivation to follow: The role of the self-regulatory focus in leadership processes. Academy of Management Review, 32, 500528.

Karelaia, N., \& Guillén, L. (2014). Me, a woman and a leader: Positive social identity and identity conflict. Organizational Behavior and Human Decision Processes, 125, 204-219.

Kellerman, B. (2012). The end of leadership. New York: Harper Collins.

Kellerman, B. (2016). Leadership-It's a System, Not a Person! Daedalus, 145(3), 83-94.

Kempster, S. (2006). Leadership learning through lived experience: A process of 
apprenticeship? Journal of Management \& Organization, 12, 4-22.

Kershaw, C., Rast III, D. E., Hogg, M. A., \& van Knippenberg, D. (2021). Divided groups need leadership: A study of the effectiveness of collective identity, dual identity, and intergroup relational identity rhetoric. Journal of Applied Social Psychology, 51, 53-62.

*Khumalo, N., Dumont, K., \& Waldus, S. (2022). Leaders' influence on collective action: An identity leadership perspective. Leadership Quarterly.

Komives, S. R., Owen, J. E., Longerbeam, S. D., Mainella, F. C., Osteen, L. (2005). Developing a leadership identity: A grounded theory. Journal of College Student Development, 46, 593-611.

Kragt, D., \& Guenter, H. (2018). Why and when leadership training predicts effectiveness: The role of leader identity and leadership experience. Leadership and Organization Development Journal, 39, 406-418.

Kroll, M. J., Toombs, L. A., \& Wright, P. (2000). Napoleon's tragic march home from Moscow: Lessons in hubris. Academy of Management Perspectives, 14, 117-128.

Krug, H., Steffens, N. K., \& Haslam, S. A. (2020). Doing it for the team: Soccer coaches' identity leadership predicts players' effort, turnover intentions, and performance. Psychology of Sport \& Exercise.

Kwok, N., Hanig, S., Brown, D. J., \& Shen, W. (2018). How leader role identity influences the process of leader emergence: A social network analysis. The Leadership Quarterly, 29, 648-662.

Kwok, N., Shen, W., \& Brown, D. J. (2021). I can, I am: Differential predictors of leader efficacy and identity trajectories in leader development. The Leadership Quarterly, 101422.

Ladkin, D. (2020). What Donald Trump's response to COVID-19 teaches us: It's time for our romance with leaders to end. Leadership, 16, 273-278.

Lanaj, K., Gabriel, A. S., \& Chawla, N. (2021). The self-sacrificial nature of leader identity: Understanding the costs and benefits at work and home. Journal of Applied Psychology, $106,345-363$.

Lee, G., Platow, M. J., Haslam, S. A., Reicher, S. D., Cruwys, T., \& Grace, D. (2021). Facilitating goals, tasks, and bonds via identity leadership: Understanding the therapeutic working alliance as the outcome of social identity processes. Group Dynamics: Theory, Research, and Practice. Advance online publication. doi: 10.1037/gdn0000170

Levine R. M., Cassidy, C., Brazier, G., Reicher S. D. (2002). Self-categorization and bystander non-intervention: Two experimental studies. Journal of Applied Social 
Psychology, 32, 1452-1463.

Lipman-Blumen, J. (2005). Toxic leadership: When grand illusions masquerade as noble visions. Leader to Leader, 36, 29-36.

Lipman-Blumen, J. (2006). The allure of toxic leaders: Why we follow destructive bosses and corrupt politicians - and how we can survive them. Oxford University Press.

Lord, R. G., \& Brown, D. G. (2004). Leadership processes and follower self-identity. Lawrence Erlbaum.

Lord, R. G., Brown, D. J., Harvey, J. L., \& Hall, R. J. (2001). Contextual constraints on prototype generation and their multilevel consequences for leadership perceptions. The Leadership Quarterly, 12, 311-338.

Lord, R. G., \& Hall, R. J. (2005). Identity, deep structure and the development of leadership skill. The Leadership Quarterly, 16, 591-615.

Lord, R. G., Foti, R. J., \& De Vader, C. L. (1984). A test of leadership categorization theory: Internal structure, information processing, and leadership perceptions. Organizational Behavior and Human Performance, 34, 343-378.

Lord, R. G., \& Maher, K. J. (1990). Perceptions of leadership and their implications in organizations. In J. S. Carroll (Ed.), Applied social psychology and organizational settings (pp. 129-154). Hillsdale, NJ: Lawrence Erlbaum.

Lord, R. G. \& Maher, K. J. (1991). Leadership and information processing: Linking perceptions and performance (pp. 129-154). London: Unwin Hyman.

McLaren, C. D., Boardley, I. D., Benson, A. J., Martin, L. J., Fransen, K., Herbison, J. D., ... \& Bruner, M. W. (2021). Follow the leader: Identity leadership and moral behaviour in social situations among youth sport teammates. Psychology of Sport and Exercise, 55, 101940.

McLean, B., \& Elkind, P. (2013). The smartest guys in the room: The amazing rise and scandalous fall of Enron. New York US: Penguin.

Maskor, M., Steffens, N. K., Peters, K. O., \& Haslam, S. A. (2021). The secrets of leadership: Insights from the commercial literature. Australian Journal of Management.

Mertens, N., Fransen, K., Haslam, S. A., Steffens, N., \& Boen, F. (2020). Leading together towards a stronger 'us': An experimental test of the effectiveness of the 5R shared leadership program $\left(5 \mathrm{R}^{\mathrm{S}}\right)$ in basketball teams. Journal of Science and Medicine in Sport, $23,750-775$

Mertens, N., Boen, F., Steffens, N. K., Haslam, S. A., Bruner, M., Barker, J B.., \& Slater, M. J., \& Fransen, K. (2021). Harnessing the power of 'us': A randomized wait-list controlled 
trial of the 5R Shared Leadership Development Program $\left(5 R^{S}\right)$ in basketball teams. Psychology of Sport \& Exercise, 24, 281-290.

Middleton, E. D., Walker, D. O., \& Reichard, R. J. (2019). Developmental trajectories of leader identity: Role of learning goal orientation. Journal of Leadership \& Organizational Studies, 26, 495-509.

Miller, A. J., Slater, M. J., \& Turner, M. J. (2021). The influence of identity leadership principles on followers' challenge and threat states and motor performance. Psychology of Sport and Exercise, 54, 101909.

Miscenko, D., Guenter, H., \& Day, D. V. (2017). Am I a leader? Examining leader identity development over time. The Leadership Quarterly, 28, 605-620.

Mols, F., Haslam, S. A., Reicher, S. D., Platow, M. J., \& Steffens, N. K. (2022). The social identity approach to political leadership. In Huddie, L., Sears, D. O., \& Levy, J. S. (Eds). The Oxford handbook of political psychology (3rd ed). Oxford University Press.

Moss, S. A., Dowling, N., \& Callanan, J. (2009). Towards an integrated model of leadership and self regulation. The Leadership Quarterly, 20, 162-176.

Mumford, M. D., \& Fried, Y. (2014). Give them what they want or give them what they need? Ideology in the study of leadership. Journal of Organizational Behavior, 35(5), 622-634.

Muir, D. (2014). Mentoring and leader identity development: A case study. Human Resource Development Quarterly, 25, 349-379.

Nye, J. L., \& Simonetta, L. G. (1996). Followers' perceptions of group leaders. The impact of recognition-based and inference-based processes. In J. Nye \& A. Brower (Eds.), What's social about social cognition? Research on socially shared cognition in small groups (pp. 124-153). Newbury Park, CA \& London: Sage.

Oakes, P. J., Haslam, S. A., \& Turner, J. C. (1994). Stereotyping and Social Reality. Oxford: Blackwell.

Oc, B. (2018). Contextual leadership: A systematic review of how contextual factors shape leadership and its outcomes. The Leadership Quarterly, 29(1), 218-235.

Pestritto, R. J. (2005). Woodrow Wilson and the roots of modern liberalism. Rowman \& Littlefield.

Peters, K., \& Haslam, S. A. (2018a). I follow, therefore I lead: A longitudinal study of leader and follower identity and leadership in the marines. British Journal of Psychology, 109, 708-723.

Peters, K. \& Haslam, S. A. (2018b). To be a good leader, start by being a good follower. 
Harvard Business Review (August 8). https://hbr.org/2018/08/research-to-be-a-goodleader-start-by-being-a-good-follower

Peters, T., \& Waterman, R. H., Jr. (1982). In search of excellence: Lessons from America's best-run companies. HarperCollins Business.

Petit, V., \& Bollaert, H. (2012). Flying too close to the sun? Hubris among CEOs and how to prevent it. Journal of Business Ethics, 108, 265-283.

Platow, M. J., Haslam, S. A., Reicher, S. D., \& Steffens, N. K. (2015). There is no leadership if no-one follows: Why leadership is necessarily a group process. International Coaching Psychology Review, 10, 20-37.

Platow, M. J., \& van Knippenberg, D. (2001). A social identity analysis of leadership endorsement: The effects of leader ingroup prototypicality and distributive intergroup fairness. Personality and Social Psychology Bulletin, 27, 1508-1519.

Platow, M. J., van Knippenberg, D., Haslam, S. A., van Knippenberg, B., \& Spears, R. (2006). A special gift we bestow on you for being representative of us: Considering leader charisma from a self-categorization perspective. British Journal of Social Psychology, 45, 303-320.

Postmes, T., \& Jetten, J. (2006). Individuality and the group: Advances in social identity. London: Sage.

Postmes, T., Haslam, S. A., \& Jans, L. (2013). A single-item measure of social identification: Reliability, validity, and utility. British Journal of Social Psychology, 52, 597-617.

Pyle, L. K. (2013). Changes in leadership self-efficacy, leader identity, capacity for socially responsible leadership, and curiosity due to a structured leader development program. Doctoral dissertation, James Madison University.

Raelin, J.A. (2016). Imagine there are no leaders: Reframing leadership as collaborative agency. Leadership, 12, 131-58.

Ramdass, J. V. (2022). Social identification processes help explain why group members pursue specific leadership opportunities. Unpublished manuscript. Claremont Graduate University.

Rast III, D. E., Hogg, M. A., \& van Knippenberg, D. (2018). Intergroup leadership across distinct subgroups and identities. Personality and Social Psychology Bulletin, 44, 10901103. 
Rast, D. E. III, van Knippenberg, D., \& Hogg, M. A. (2019). Intergroup relational identity: Development and validation of a scale and construct. Group Processes and Intergroup Relations, 23, 943-966.

Reicher, S. D., \& Haslam, S. A. (2006). Rethinking the psychology of tyranny: The BBC Prison Study. British Journal of Social Psychology, 45, 1-40.

Reicher, S. D. \& Haslam, S. A. (2017). The politics of hope: Donald Trump as an entrepreneur of identity. In M. Fitzduff (Ed.), The myth of rational politics: Understanding the allure of Trumpism (pp.25-39). Praeger.

Reicher, S. D., Haslam, S. A., \& Hopkins, N. (2005). Social identity and the dynamics of leadership: Leaders and followers as collaborative agents in the transformation of social reality. The Leadership Quarterly, 16, 547-568.

Reicher, S. D., Haslam, S. A., \& Smith, J. R. (2012). Working towards the experimenter: Reconceptualizing obedience within the Milgram paradigm as identification-based followership. Perspectives on Psychological Science, 7, 315-324.

Reicher, S. D., \& Hopkins, N. (2001). Self and nation: Categorization, contestation and mobilisation. Sage.

Rosch, E. (1978). Principles of categorization. In E. Rosch, and B. B. Lloyd (Eds), Cognition and categorization (pp. 27-48). Erlbaum.

Rosenthal, S. A., \& Pittinsky, T. L. (2006). Narcissistic leadership. The Leadership Quarterly, 17, 617-633.

Rost, J. C. (2008) Leadership definition. In A. Marturano \& J. Gosling (Eds.) Leadership: The key concepts (pp. 94-99). New York: Routledge.

Rus, D., van Knippenberg, D., \& Wisse, B. (2010). Leader self-definition and leader selfserving behavior. The Leadership Quarterly, 21, 509-529.

Ryan, M. K., \& Haslam, S. A. (2007). The glass cliff: Exploring the dynamics surrounding the appointment of women to precarious leadership positions. Academy of Management Review, 32, 549-572.

Sandel, M. J. (2020). The tyranny of merit: What's become of the common good? Penguin.

Scholl, A., Sassenberg, K., Ellemers, N., Scheepers, D., \& De Wit, F. (2018). Highly identified power-holders feel responsible: The interplay between social identification and social power within groups. British Journal of Social Psychology, 57, 112-129.

Schyns, B., Kiefer, T., Kerschreiter, R., \& Tymon, A. (2011). Teaching implicit leadership theories to develop leaders and leadership: How and why it can make a difference. Academy of Management Learning and Education, 10, 397-408. 
*Selvanathan, H. P., Crimston, C., \& Jetten, J. (2022). How being rooted in the past can shape the future: The role of social identity continuity in the wish for a strong leader. Leadership Quarterly.

Sieweke, J., \& Santoni, S. (2020). Natural experiments in leadership research: An introduction, review, and guidelines. The Leadership Quarterly, 31(1), 101338.

*Sewell, D. K., Ballard, T., \& Steffens, N. K. (2021). Exemplifying “Us": Integrating social identity theory of leadership with cognitive models of categorization. The Leadership Quarterly, 101517.

Slater, M. J., \& Barker, J. B. (2019). Doing social identity leadership: Exploring the efficacy of an identity leadership intervention on perceived leadership and mobilization in elite disability soccer. Journal of Applied Sport Psychology, 31, 65-86.

Sluss, D. M., \& Ashforth, B. E. (2007). Relational identity and identification: Defining ourselves through work relationships. Academy of management review, 32, 9-32.

Sluss, D. M., van Dick, R., \& Thompson, B. S. (2011). Role theory in organizations: A relational perspective. In S. Zedeck (ed.), APA handbook of industrial and organizational psychology. Vol 1: Building and helping the organization (pp. 505-534). American Psychological Association.

Smith, P., Haslam, S. A., \& Nielsen, J. F. (2018). In search of identity leadership: An ethnographic study of emergent influence in an interorganizational R\&D team. Organization Studies, 39, 1425-1447.

Steffens, N., \& Haslam, S. A. (2013). Power through 'us': Leaders' use of we-referencing language predicts election victory. PLoS ONE, 8(10): e77952.

Steffens, N. K., \& Haslam, S. A. (2021). The narcissistic appeal of leadership theories. American Psychologist. Advance online publication. doi: https://doi.org/10.1037/amp0000738

Steffens, N., Haslam, S. A., Kessler, T., \& Ryan, M. K. (2013). Leader performance and prototypicality: Their inter-relationship and impact on leaders' identity entrepreneurship. European Journal of Social Psychology, 43, 606-613.

Steffens, N. K., Haslam, S. A., Peters, K., \& Quiggin, J. (2020). Identity economics meets identity leadership: Exploring the consequences of elevated CEO pay. The Leadership Quarterly, 30, 101269.

Steffens, N. K., Haslam, S. A., \& Reicher, S. D. (2014). Up close and personal: Evidence that shared social identity is a basis for the 'special' relationship that binds followers to leaders. The Leadership Quarterly, 25, 296-313. 
Steffens, N. K., Haslam, S. A., Reicher, S. D., Platow, M. J., Fransen, K., Yang, J., Ryan, M. K., Jetten, J., Peters, K., \& Boen, F. (2014). Leadership as social identity management: Introducing the Identity Leadership Inventory (ILI) to assess and validate a fourdimensional model. The Leadership Quarterly, 25, 1001-1024.

Steffens, N. K., Munt, K. A., van Knippenberg, D., Platow, M. J., \& Haslam, S. A. (2021a). Advancing the social identity theory of leadership: A meta-analytic review of leader group prototypicality. Organizational Psychology Review, 11, 35-72.

Steffens, N. K., Peters, K., Kark, R. \& Haslam, S. A. (2022). Leading through 'I' versus 'we': Comparing the predictive profile of leaders' concern for leader identity and social identity. Unpublished manuscript: University of Queensland.

Steffens, N. K., Slade, E., Haslam, S. A., Stevens, M., \& Rees, T. (2019). Putting the 'we' into workout: The association of identity leadership with exercise class attendance and effort, and the mediating role of group identification and comfort. Psychology of Sport \& Exercise, 45, 101544.

Steffens, N. K., Yang, J., Jetten, J., Haslam, S. A., \& Lipponen, J. (2018). The unfolding impact of leader identity entrepreneurship on burnout, work engagement, and turnover intentions. Journal of Occupational Health Psychology, 23, 373-387.

Stevens, M., Rees, T., \& Cruwys, T. (2021). Social identity leadership in sport and exercise: Current status and future directions. Psychology of Sport and Exercise, 101931.

Stevens, M., Rees, T., Coffee, P., Steffens, N. K., \& Polman, R. \& Haslam, S. A. (2019). Leaders' creation of shared identity impacts group members' effort and performance: Evidence from an exercise task. PLoS ONE, 14(7): e0218984

Stets, J. E., \& Burke, P. J. (2000). Identity theory and social identity theory. Social Psychology Quarterly, 63, 224-237.

Swann Jr, W. B., Gómez, A., Seyle, D. C., Morales, J., \& Huici, C. (2009). Identity fusion: The interplay of personal and social identities in extreme group behavior. Journal of Personality and Social Psychology, 96, 995-1011.

Swann Jr, W. B., Jetten, J., Gómez, Á., Whitehouse, H., \& Bastian, B. (2012). When group membership gets personal: a theory of identity fusion. Psychological Review, 119, 441.

Tajfel, H. (1972). La categorisation sociale (English trans.). In S. Moscovici (Ed.), Introduction å la psychologie sociale (Vol. 1, pp. 272-302). Larousse.

Tajfel, H. \& Turner, J.C. (1979). An integrative theory of intergroup conflict. In W.G. Austin $\&$ S. Worchel (eds), The social psychology of intergroup relations (pp. 33-47). Brooks/Cole. 
Thomas, E. F., McGarty, C., \& Mavor, K. I. (2009). Aligning identities, emotions, and beliefs to create commitment to sustainable social and political action. Personality and Social Psychology Review, 13, 194-218.

Todorov, A. (2017). Face Value: The Irresistible Influence of First Impressions: Princeton University Press.

Todorov, A., Mandisodza, A. N., Goren, A., \& Hall, C. C. (2005). Inferences of competence from faces predict election outcomes. Science, 308(5728), 1623-1626.

Tourish, D. (2013). The dark side of transformational leadership: A critical perspective. London \& New York: Routledge.

Truninger, M., Ruderman, M. N., Clerkin, C., Fernandez, K. C., \& Cancro, D. (2020). Sounds like a leader: An ascription-actuality approach to examining leader emergence and effectiveness. The Leadership Quarterly, Advance online publication. doi: https://doi.org/10.1016/j.leaqua.2020.101420

Tubbs, S. L., \& Schulz, E. (2006). Exploring a taxonomy of global leadership competencies and meta-competencies. Journal of American Academy of Business, 8, 29-34.

Turner, J. C. (1982). Towards a cognitive redefinition of the social group. In H. Tajfel (Ed.), Social identity and intergroup relations (pp. 15-40). Cambridge: Cambridge University Press. (p.21)

Turner, J. C. (1991). Social influence. Milton Keynes: Open University Press.

Turner, J. C. (2005). Examining the nature of power: A three-process theory. European Journal of Social Psychology, 35, 1-22.

Turner, J. C., \& Haslam, S. A. (2001). Social identity, organizations and leadership. In M. E. Turner (Ed.), Groups at work: Advances in theory and research (pp. 25-65). Hillsdale, NJ: Erlbaum.

Turner, J. C., Hogg, M. A., Oakes, P. J., Reicher, S.D., \& Wetherell, M. S. (1987). Rediscovering the social group: A self-categorization theory. Blackwell.

Turner, J. C., Oakes, P. J., Haslam, S. A., \& McGarty, C. A. (1994). Self and collective: Cognition and social context. Personality and Social Psychology Bulletin, 20, 454-463. Tyler, T. R., \& Blader, S. (2003). The group engagement model: Procedural justice, social identity, and cooperative behavior. Personality and Social Psychology Review, 7, 349-361.

van Dick, R., Lemoine, J. E., Steffens, N. K., Kerschreiter, R., Akfirat, S. A., Avanzi, L., ... \& Haslam, S. A. (2018). Identity leadership going global: Validation of the Identity Leadership Inventory across 20 countries. Journal of Occupational and Organizational 
Psychology, 91, 697-728.

van Dick, R. \& Kerschreiter, R. (2016). The social identity approach to effective leadership:

An overview and some ideas on cross-cultural generalizability. Frontiers of Business Research in China, 10, 363-384.

Van Hoorn, A. (2014). Individualism and the cultural roots of management practices. Journal of Economic Behavior \& Organization, 99, 53-68.

van Knippenberg, B., van Knippenberg, D., De Cremer, D., \& Hogg, M. A. (2005). Research in leadership, self, and identity: A sample of the present and a glimpse of the future. The Leadership Quarterly, 16, 495-499.

van Knippenberg, D. (2011). Embodying who we are: Leader group prototypicality and leadership effectiveness. The Leadership Quarterly, 22, 1078-1091.

van Knippenberg, D. (2012). Leadership: A person-in-situation perspective. In K. Deaux \& M. Snyder (Eds.), The Oxford handbook of personality and social psychology (pp. 673700). Oxford University Press.

van Knippenberg, D., van Knippenberg, B., De Cremer, D., \& Hogg, M. A. (2004).

Leadership, self, and identity: A review and research agenda. The Leadership

Quarterly, 15, 825-856.

Waring, P. (1999). The rise of individualism in Australian industrial relations. New Zealand Journal of Employment Relations, 24, 291-318.

Weber, M. (1947). The theory of social and economic organization (A. M. Henderson \& T. Parsons, Trans. \& Eds.). New York: Oxford University Press. (Originally published 1922)

Yaffe, T., \& Kark, R. (2011). Leading by example: The case of leader OCB. Journal of Applied Psychology, 96, 806-826.

Zheng, W., Meister, A., \& Caza, B. B. (2021). The stories that make us: Leaders' origin stories and temporal identity work. Human Relations, 74, 1178-1210.

Zheng, W., \& Muir, D. (2015). Embracing leadership: A multi-faceted model of leader identity development. Leadership \& Organization Development Journal, 6, 630-656. 